\title{
Observational Study on Formation of a Localized Rainfall on a Basin with Heat and Aridity on Days of Weak Synoptic Disturbance in Summer
}

\author{
Tetsuya SANO \\ National Institute of Information and Communications Technology, Tokyo, Japan \\ and \\ Satoru OISHI \\ Research Center for Urban Safety and Security, Kobe University, Hyogo, Japan
}

(Manuscript received 30 September 2016, in final form 9 November 2017)

\begin{abstract}
To elucidate the formation of localized rainfall in a basin with heat and aridity under a weak synoptic disturbance in summer, we described the characteristics of atmospheric conditions on the Kofu Basin preceding the appearance of primary precipitating cells from 23 localized rainfall events on the Kofu Basin on days of weak synoptic disturbance at the surface from 1 June to 30 September in 2012 to 2014. Furthermore, on the basis of a case study of an event on 25 July 2014, the formation of the atmospheric conditions was described from the standpoint of moisture behavior.

Owing to the thermal contrast between the Kofu Basin with heat and aridity and the outside environment, the south-component wind blowing in the valley connecting to the coastal region of Suruga Bay and the eastcomponent wind blowing in the valley connecting to the Kanto Plain entered the basin as southwesterly wind and southeasterly wind, respectively, which caused an increase in the water vapor mixing ratio and a slight decrease in temperature at the surface. Thereafter, the amount of precipitable water vapor derived from the global navigation satellite system observations (GNSS-PWV) in the central region of the Kofu Basin increased abruptly after the moderate increase in GNSS-PWV at all the observation points in the basin. Finally, a cloud appeared over the local region between the southwesterly wind and the southeasterly wind and precipitating cells appeared at that location at 3.25 to $6.25 \mathrm{~km}$ above sea level.

We discussed the moisture transport into the Kofu Basin, the concentration of that moisture in a local region, and the appearance of precipitating cells. This is an example of the formation of atmospheric conditions leading to localized rainfall in a basin with heat and aridity.
\end{abstract}

Keywords localized rainfall; surface wind; moisture transport; precipitating cell; Kofu Basin

Corresponding author: Tetsuya Sano, National Institute of Information and Communications Technology, 4-2-1 Nukuikitamachi, Koganei, Tokyo 184-8795, Japan

E-mail: tsano@nict.go.jp

J-stage Advance Published Date: 21 December 2017

\section{Introduction}

In summer, a localized rainfall, which is caused by a convective precipitating system composed of precipitating cells, often occurs almost everywhere on a day of weak synoptic disturbance. In a basin with heat and aridity in summer, however, both the number 
of rainfall events and the amount of rainfall tend to be small because of unfavorable conditions for the development of cumulus convection during the daytime due to subsidence associated with valley wind circulation (Fujibe 1988). At the same time, Saito and Kimura (1998) reported an increase in the number of convective rainfall events in basins and valleys under weak synoptic disturbance in the afternoon to evening, in close agreement with the increase in latent heat in basins and valleys (Kimura and Kuwagata 1995). Thus, localized rainfall that occurs in a basin with heat and aridity under a weak synoptic disturbance in summer has generated interest in the changing to favorable atmospheric conditions to cause a convective precipitating system, and the moisture transport to a basin in water local circulation process associated with thermally induced local circulation.

Local subsidence heating in valleys and moisture transport to mountains are caused by valley wind circulation. Moisture transport to a basin is caused by wind to the basin from the surrounding mountains, which is associated with the return flow of valley wind circulation (Kimura and Kuwagata 1993, 1995). Kuwagata and Kimura (1995) and Iwasaki and Miki (2001) reported from sounding observations that the water vapor mixing ratio at 1.5 to $3.0 \mathrm{~km}$ above mean sea level (ASL) on a valley and a semi-basin increased in the afternoon and evening, arguing that this increase was due to moisture transport from mountains to the valley and the semi-basin by the return flow associated with thermally induced local circulation and/or ambient wind. Sato and Kimura (2005) found by numerical simulation that the moisture advection at $800 \mathrm{hPa}$ from mountains to their feet contributes to the increase in convective instability on their feet.

Furthermore, to generate a convective precipitating system in a basin, moisture advection and horizontal convergence at the surface or in the lower layer are required. Iwasaki (2004) analyzed the diurnal variation of precipitable water and convective activity for sunny summer days around Mt. Tanigawa in the northern Kanto region of Japan. He found that the increase in the amount of precipitable water in the semi-basin from afternoon to late evening was caused by both moisture advection from the mountains and moisture convergence from the extended sea breeze at the surface, which resulted in an unstable atmosphere over the semi-basin. Chen et al. (2010) revealed that, for a heavy rainfall event in the Taipei Basin, wind convergence was caused by the inflows associated with prevailing winds going around the terrain, which triggered the convective precipitating system. For the formation of localized rainfall over a basin with heat and aridity under weak synoptic disturbance, however, process of moisture transport to the basin and its concentration in the local region, which is connected to the formation of a convective precipitating system, has not been sufficiently understood.

The Kofu Basin, in central Japan, is surrounded by mountains with heights of 1 to $3 \mathrm{~km}$ (Figs. 1a, b). The Kofu Basin is often hot and dry during summer. Sano et al. (2012a) indicated that the average rainfall amount from June to October in 2004 to 2007 in the Kofu Basin was less than that on the surrounding mountains. However, localized rainfall during summer can occur in the Kofu Basin, as well as in the surrounding mountains (Sano et al. 2012a, 2014), which is largely coincident with the report of Saito and Kimura (1998). Thus, it is suggested that the localized rainfall, which often occur in the Kofu Basin under weak synoptic disturbance, results from the moisture transport to a basin with heat and aridity and the moisture concentration in the local region.

In this study, to elucidate the formation of localized rainfall in a basin with heat and aridity under weak synoptic disturbance in summer, we focused on the changes in atmospheric conditions in the Kofu Basin preceding the appearance of precipitating cells composed of a convective precipitating system. First, we analyze the appearance distribution of the primary precipitating cells over the Kofu Basin under weak synoptic disturbance, and the surface wind and temperature distributions and the stability of the atmosphere over the Kofu Basin before the appearance of the primary precipitating cell on the Kofu Basin using several observation cases. Then, we analyze the appearance distributions of clouds and precipitating cells composing a convective precipitating system, and the temperature, wind and water vapor mixing ratio at the surface, and the precipitable water vapor on the Kofu Basin before the appearance of precipitating cells from a case study. Thus, we discuss the formation of atmospheric conditions over the Kofu Basin that lead to the formation of precipitating cells through these analyses.

\section{Observations and data}

The Kofu Basin, which is surrounded by mountains, is connected to the outside through valleys (Fig. 1b). One valley connects the coastal region of Suruga Bay, while the other leads the Kanto Plain via the mountain pass between Mts. Misaka and Mt. Daibosatsu.

In this study, we used meteorological observation data obtained at the surface of the Kofu Basin (Figs. 
$1 \mathrm{~b}, \mathrm{c})$. Meteorological phenomena at the surface were observed at Kofu, Nirasaki, Katsunuma, Kiriishi, Furuseki, Ooizumi, Nanbu, Ootsuki, Yamanaka, and Kawaguchiko by the Japan Meteorological Agency (JMA); at Kamihatta, Kosaiminami, Shimoimai, and Atoyashiki by the environmental sensing system of NTT DOCOMO, Inc.; and at Kasugai by University of Yamanashi. Surface meteorological observation were conducted on a continuous basis by the JMA, while those of NTT DOCOMO, Inc., and University of Yamanashi were conducted from 22 July to 22 September 2014. Surface temperature and winds were observed every $10 \mathrm{~min}$ at all observation points, and surface pressure and relative humidity were observed every $10 \mathrm{~min}$ at Kofu, Kawaguchiko, Kamihatta, Kosaiminami, Shimoimai, Atoyashiki, and Kasugai.

We also used precipitable water vapor data at Nirasaki, Nakamichi, and Makioka, which were derived from observations made by the global navigation satellite system (GNSS-PWV) of the Geospatial Information Authority of Japan (GSI). To derive GNSSPWVs at Nirasaki, Nakamichi, and Makioka, the surface pressure and temperature data at Kamihatta, Shimoimai and Atoyashiki were used, respectively, with altitude correction (Bavis et al. 1992).

To obtain precipitation data in the Kofu Basin, we used an X-band multi-parameter radar installed at the Kofu Campus of University of Yamanashi (Fig. 1b), named 'UYR'. An observational radius of the UYR is $61.75 \mathrm{~km}$, which allows it to cover the entire Kofu Basin. The specifications for the UYR are shown in Table 1 and are the same as those shown by Sano et al. (2012b). The UYR performs volume scans at intervals of 5 min including plan position indicators (PPIs) at antenna elevation angles of $1.0^{\circ}, 1.8^{\circ}, 2.5^{\circ}, 3.6^{\circ}, 4.8^{\circ}$, $6.6^{\circ}, 8.8^{\circ}, 11.5^{\circ}, 15.2^{\circ}, 19.7^{\circ}, 25.6^{\circ}$, and $32.6^{\circ}$. For the observation of the target, the UYR observations at low antenna elevation angles are unable to provide sufficient data on the target area because the beams are blocked by the low mountains close to the UYR; therefore, there were no observation data from the lower layer. There were also no observation data from the upper layer because of the volume scan with a limited antenna elevation angles. The parameters used in this study are the horizontal radar reflectivity factor, $Z_{H}$; the differential reflectivity, $Z_{D R}$; the specific differential phase, $K_{D P}$; and the Doppler velocity, $D V$. These parameters were interpolated to Cartesian coordinates using the method of Cressman (1959); the horizontal and vertical grid intervals were both $500 \mathrm{~m}$. To express the three-dimensional distributions of the parameters, a correction related to the movement of the radar echo was made using the method of Gal-Chen (1982). The central time for the correction was 3 min after the start of each volume scan.

For the analysis of environmental conditions on the Kofu Basin, we used the data from the meso-scale model of the JMA (JMA-MSM; Saito et al. 2006) distributed by the Japan Meteorological Business Support Center with a horizontal resolution of $10 \mathrm{~km}$ (Fig. 1d). Then, the mesoscale objective analysis of the JMA (JMA-MANAL; Honda et al. 2005) with a horizontal resolution of $5 \mathrm{~km}$ was used for the discussion in this study. The terrain data for JMAMSM and JMA-MANAL resolve the Kofu Basin, the valley connecting it to the coastal region of Suruga Bay, and the valley connecting it to the Kanto Plain via the mountain pass between Mts. Misaka and Mt. Daibosatsu (Fig. 1d).

In addition, satellite observations data from MTSAT-2, weather charts published by the JMA, and upper-air sounding data at Hamamatsu were used.

Table 1. Specifications for the X-band dual- polarimetric Doppler radar at the University of Yamanashi (Sano et al. 2012b).

$\begin{array}{ll}\text { Transmitting Polarization } & \text { Horizontal and Vertical Polarizations }(\mathrm{H}, \mathrm{V}) \\ \text { Transmitter } & \text { Solid state }(\mathrm{H}, \mathrm{V}) \\ \text { Transmitting Frequency } & 9,720 \mathrm{MHz}(\mathrm{H}, \mathrm{V}) \\ \text { Transmitting Power } & 200 \mathrm{~W}(\mathrm{H}, \mathrm{V}) \\ \text { Width of Pulse } & \text { Short: } 1 \mu \mathrm{s}, \text { Long: } 32 \mu \mathrm{s} \text { with pulse compression } \\ \text { Width of Beam (H-axis } \times \text { V-axis) } & 1.04^{\circ} \times 1.03^{\circ}, 1.09^{\circ} \times 1.05^{\circ}(\mathrm{H}, \mathrm{V}) \\ \text { Pulse Reprtition Frequency } & 1,600 \mathrm{~Hz} \text { and } 2,000 \mathrm{~Hz}(\mathrm{dual} \text { PRF system }) \\ \text { Maximum Observational Range } & 61.75 \mathrm{~km} \\ \text { Resolution of Distance } & 150 \mathrm{~m} \\ \text { Observed Raw Data } & \text { Received power }\left(\operatorname{Pr}_{H}, \operatorname{Pr}_{V}\right), \text { Raw Doppler velocity }(D V r), \\ & \text { Width of Doppler velocity }(D W r), \text { Total differential phase }\left(\psi_{D P}\right), \\ & \text { and Correlation coefficient }\left(\rho_{H V}\right)\end{array}$


(a)

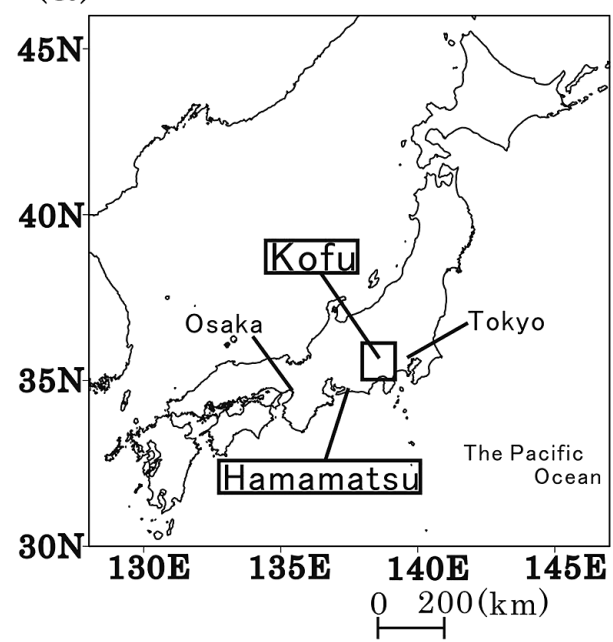

(b)

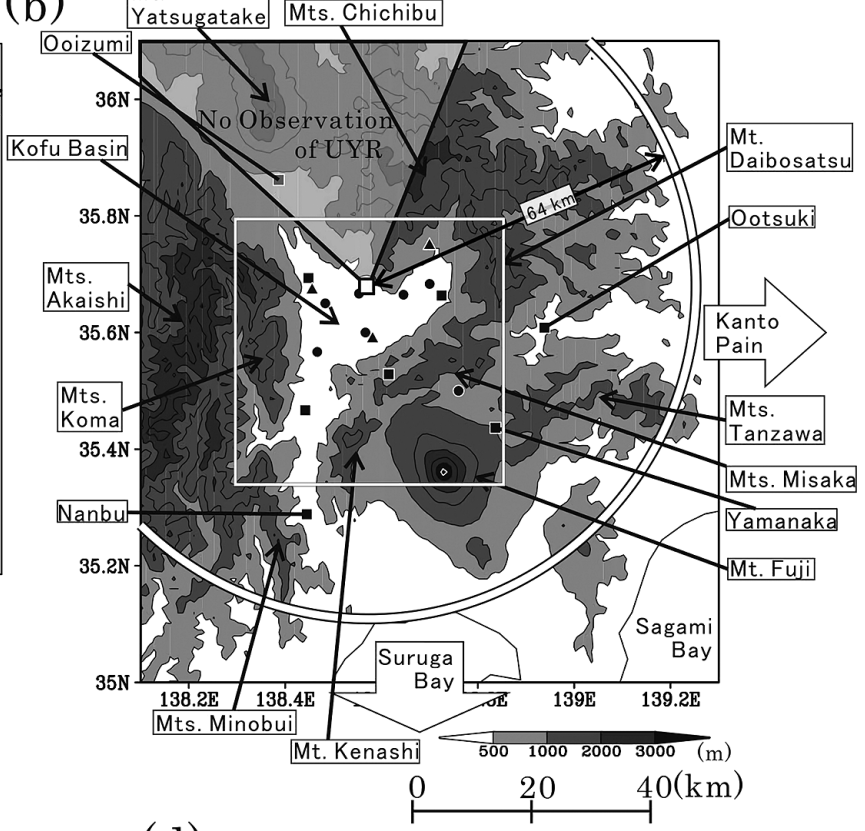

(d)

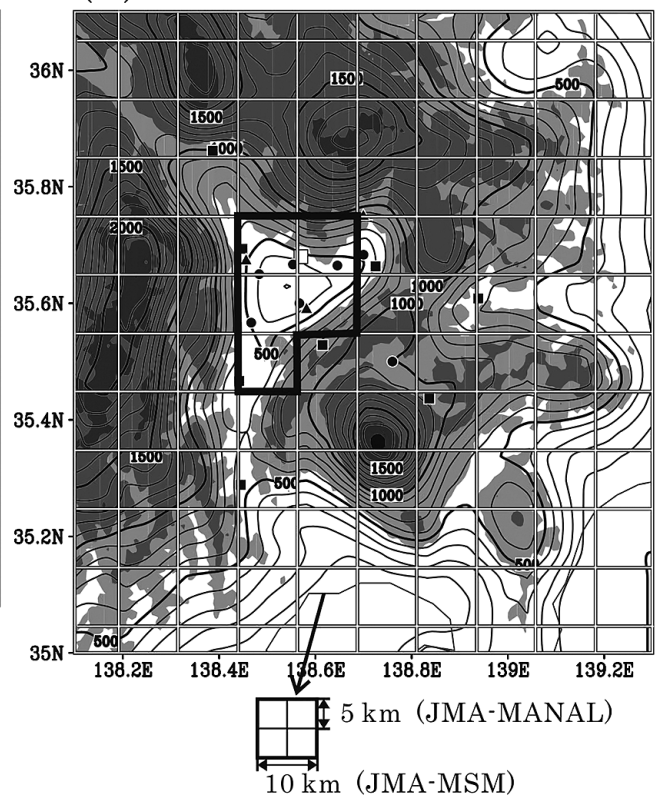

Fig. 1. (a) Map of Japan. (b) Position and observational range of the X-band multi-parameter radar of University of Yamanashi ( $\square$ and white circle, respectively) and the positions of surface meteorological observations (• and $\boldsymbol{\square}$ ) and GNSS receiver ( $\boldsymbol{\Delta})$ with a detailed terrain map of Kofu Basin and the surrounding mountains. This research area is indicated by the black rectangle in (a). The contours with shaded areas indicate terrain with a contour interval of $500 \mathrm{~m}$ beginning at $500 \mathrm{~m}$ ASL. (c) Positions of UYR, surface meteorological observation and GNSS receivers with a detailed terrain map of the Kofu Basin. The contours with shaded areas indicate terrain every $500 \mathrm{~m}$. This area corresponds to the white rectangle in (b). (d) Terrains and grids used for JMAMSM and JMA-MANAL with the terrain data in (b). The contours indicate terrains usage for JMA-MSM and JMA-MANAL at $100 \mathrm{~m}$ intervals. The grid size in (d) is $10 \mathrm{~km}$ in horizontal section for JMA-MSM. The grid size for JMA-MANAL is $5 \mathrm{~km}$ in horizontal section. The area surrounding the black line indicates the Kofu Basin for the investigation of vertical atmospheric conditions using JMA-MSM. 
This study used Local Standard Time (LST $=$ UTC + nine hours). The wind direction is written in abbreviated form. For example, west-southwesterly and north-northeasterly are abbreviated as 'WSW-ly' and 'NNE-ly', respectively.

\section{Characteristics of the appearance of localized rainfall on the Kofu Basin under weak synoptic disturbance at surface in summer}

Sano et al. (2014) discussed the appearance of precipitating cells in the central region of the Kofu Basin in conjunction with the characteristics of surface winds. On the basis of the discussion on the characteristics of the rainfall that occurred on the Kofu Basin on a day of weak synoptic disturbance in summer, we investigated the appearance positions of the primary precipitating cells on the Kofu Basin, the atmospheric conditions preceding this appearance, and the amount and distribution of rainfall. In this study, we focused on the precipitating cells that occurred on the Kofu Basin. Thus, we ignored the precipitating cells occurring on or propagating from the surrounding mountains.

The period of the analysis was from 1 June to 30 September (122 days) for 3 years (2012 to 2014). First, we selected the days with weak synoptic disturbance at the surface: the chosen days had no tropical low, extratropical low, or fronts over or around the Kofu Basin according to a surface weather chart at 09:00 LST. From these days, we selected the cases in which a cellular echo composing an echo system was observed first by the UYR above $2 \mathrm{~km}$ ASL on the Kofu Basin between 12:00 and 24:00 LST. We refer to this cellular echo as a primary cellular echo. For a cellular echo, Shusse et al. (2005) and Sano and Tsuboki (2006) defined a cellular echo as a strong and closed echo with $Z_{H}$ larger than 20 or $30 \mathrm{dBZ}$, respectively. Sano et al. (2012b) indicated that the structure of a cellular echo was broken when the $Z_{H}$ became less than $40 \mathrm{dBZ}$. In this study, a cellular echo was defined as an isolated echo with $Z_{H} \geq 30 \mathrm{dBZ}$, which corresponds to a precipitating cell that is sufficiently developed. In previous studies, an echo system is defined as the concentration of cellular echoes in an area of $Z_{H} \geq 10 \mathrm{dBZ}$, which corresponds to a convective precipitating system that includes developing, developed and weakening precipitating cells.

\subsection{Appearance distribution of primary cellular echoes and distribution of rainfall amounts}

The number of days of weak synoptic disturbance at the surface was 240 in the period of the analysis.
Among these days, there were 23 cases of a primary cellular echo appearing on the Kofu Basin (Table 2). Figure 2 shows the appearance positions of these primary cellular echoes. Here, the appearance positions and altitudes were determined by $Z_{H}$ in a three-dimensional grid that was prepared using volume scan data from the UYR observation. There were 4 cases in which the altitudes of the cellular echoes that appeared near the UYR were uncertain because only low-level observations were conducted in the sight of the UYR. The appearance positions of the primary cellular echoes were concentrated in the central to eastern regions (from $138.58^{\circ} \mathrm{E}$ to $138.72^{\circ} \mathrm{E}$ and from $35.6^{\circ} \mathrm{N}$ to $35.69^{\circ} \mathrm{N}$ ), except in 3 cases, which conforms to the results of Sano et al. (2014). The appearance altitudes of the primary cellular echoes were between 2.25 and $6.25 \mathrm{~km} \mathrm{ASL}$, which indicates the formation of precipitation at large heights, suggesting the upward moisture transport.

Rainfall amount was estimated using $Z_{H}$ and $K_{D P}$ by the method of Park et al. (2005), and was selected as the maximum value between the surface elevation and $2.25 \mathrm{~km}$ ASL in each grid. The maximum rainfall amounts in all the cases ranged from $6.7 \mathrm{~mm}$ in 20 min on 25 July 2014 to $53.0 \mathrm{~mm}$ in $100 \mathrm{~min}$ on 12 September 2013 (Table 2). Figure 3 shows examples of the horizontal distribution of rainfall amounts from three cases. On 2 August 2012, a band with a large rainfall amount extended into the western region of the basin from the primary cellular echo, which appeared in the east (Fig. 3a). On 12 September 2013, an area of rainfall extended widely from the primary cellular echo that appeared in the southern region (Fig. 3b). Finally, on 25 July 2014, a narrow area with a small rainfall amount extended from its primary cellular echo in the east (Fig. 3c). While the distribution of the rainfall amount differed in each case, the rainfall in the Kofu Basin in all the cases originated in the primary precipitating cell.

\subsection{Atmospheric instability above the Kofu Basin}

To describe the atmospheric conditions over the Kofu Basin with the appearance of the primary cellular echoes, the convective instability index (CII), which is defined as the difference between the saturation equivalent potential temperature at $500 \mathrm{hPa} \theta \mathrm{e}^{*}$ $(500 \mathrm{hPa})$ and the equivalent potential temperature at $800 \mathrm{hPa} \theta \mathrm{e}(800 \mathrm{hPa})\left(\mathrm{CII}=\theta \mathrm{e}^{*}(500 \mathrm{hPa})-\theta \mathrm{e}(800\right.$ $\mathrm{hPa}$ ); Sato and Kimura 2005), was analyzed every three hours from 06:00 to 21:00 LST for each case on the Kofu Basin using the initial values employed in the prediction of JMA-MSM, which are called "the initial 


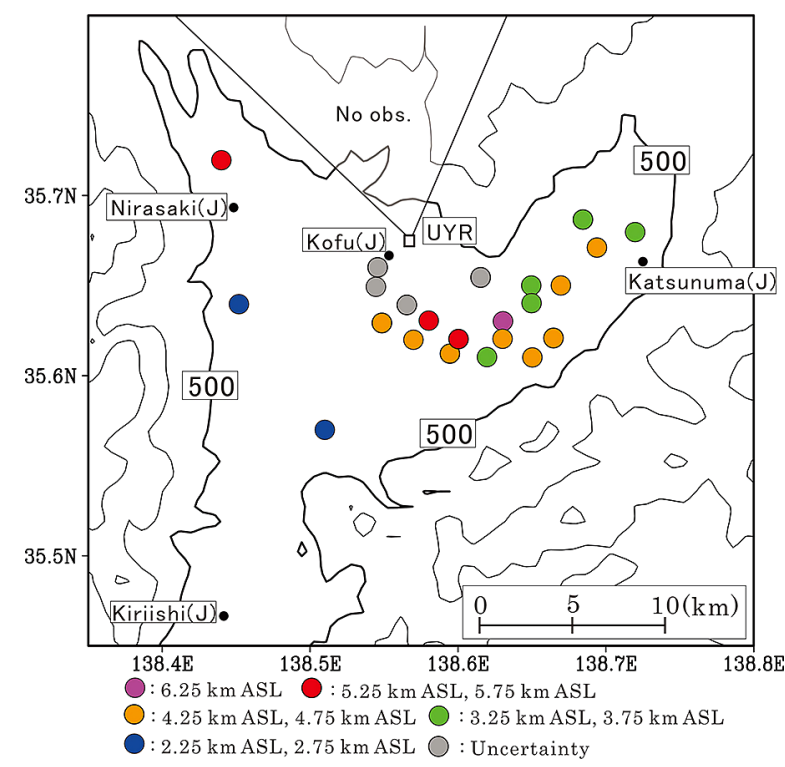

Fig. 2. Appearance points of primary cellular echoes for all cases. The colors of the dots indicate the appearance altitudes of the primary precipitating cells. The black contours indicate the $500 \mathrm{~m}$ elevations with beginning at $500 \mathrm{~m}$ ASL.

Table 2. Dates, times and positions of the appearance of primary precipitating cells, surface wind direction before the appearance of primary precipitating cells and maximum rainfall amounts in 23 events.

\begin{tabular}{|c|c|c|c|c|c|c|}
\hline \multirow{2}{*}{ Date of case } & \multirow{2}{*}{$\begin{array}{l}\text { Time of the } \\
\text { appearance of a } \\
\text { primary precip- } \\
\text { itating cell on } \\
\text { the Kofu Basin } \\
\text { (LST) }\end{array}$} & \multicolumn{3}{|c|}{$\begin{array}{l}\text { Position of the appearance } \\
\text { of a primary precipitating cell }\end{array}$} & \multirow{2}{*}{$\begin{array}{l}\text { Surface wind } \\
\text { direction at } \\
\text { Kofu before the } \\
\text { appearance of a } \\
\text { primary precipi- } \\
\text { tating cell }\end{array}$} & \multirow{2}{*}{$\begin{array}{l}\text { Maximum rainfall } \\
\text { amount on the } \\
\text { Kofu Basin } \\
\text { estimated by } \\
\text { UYR observation } \\
\left(\mathrm{mm} \text { minute }^{-1}\right)\end{array}$} \\
\hline & & $\begin{array}{l}\text { Degree of } \\
\text { longitude }\left({ }^{\circ} \mathrm{E}\right)\end{array}$ & $\begin{array}{l}\text { Degree of } \\
\text { latitude }\left({ }^{\circ} \mathrm{N}\right)\end{array}$ & $\begin{array}{l}\text { Height } \\
\text { (km ASL) }\end{array}$ & & \\
\hline 26 July 2012 & $15: 58$ & 138.58 & 35.63 & 4.25 & SSW & $24.5 / 35$ \\
\hline 02 August 2012 & $13: 48$ & 138.66 & 35.62 & 4.25 & SW & $50.9 / 80$ \\
\hline 23 August 2012 & $15: 53$ & 138.56 & 35.64 & $\begin{array}{c}\text { Uncertainty } \\
(\geq 2.75)\end{array}$ & SSW & $30.3 / 40$ \\
\hline 25 August 2012 & $16: 13$ & 138.61 & 35.65 & $\begin{array}{l}\text { Uncertainty } \\
(\geq 3.75)\end{array}$ & SW & $21.5 / 40$ \\
\hline 27 August 2012 & $16: 03$ & 138.68 & 35.69 & 3.25 & SW & $23.0 / 40$ \\
\hline 31 August 2012 & $14: 23$ & 138.60 & 35.62 & 5.25 & SW & $39.9 / 50$ \\
\hline 12 September 2012 & $14: 53$ & 138.55 & 35.63 & 4.25 & SE & $26.9 / 45$ \\
\hline 14 September 2012 & $13: 13$ & 138.54 & 35.66 & $\begin{array}{l}\text { Uncertainty } \\
(\geq 4.75)\end{array}$ & SE & $23.4 / 25$ \\
\hline 24 June 2013 & $13: 23$ & 138.72 & 35.68 & 3.25 & SW & $29.6 / 70$ \\
\hline 27 July 2013 & 18:03 & 138.44 & 35.72 & 5.25 & $\mathrm{SE}$ & $20.9 / 35$ \\
\hline 07 August 2013 & $15: 53$ & 138.58 & 35.63 & 5.25 & SSE & $37.6 / 40$ \\
\hline 10 August 2013 & $16: 03$ & 138.63 & 35.63 & 6.25 & SSW & $25.9 / 40$ \\
\hline 15 August 2013 & $14: 58$ & 138.65 & 35.61 & 4.75 & SW & $39.8 / 65$ \\
\hline 23 August 2013 & $14: 58$ & 138.57 & 35.62 & 4.75 & WNW & $14.6 / 15$ \\
\hline 12 September 2013 & $18: 48$ & 138.51 & 35.57 & 2.25 & WNW & $53.0 / 100$ \\
\hline 09 June 2014 & $15: 38$ & 138.55 & 35.65 & $\begin{array}{l}\text { Uncertainty } \\
(\geq 2.75)\end{array}$ & SE & $30.0 / 95$ \\
\hline 10 June 2014 & $15: 33$ & 138.62 & 35.61 & 3.25 & SSE & $15.5 / 30$ \\
\hline 26 June 2014 & $14: 53$ & 138.65 & 35.65 & 3.75 & SW & $39.9 / 85$ \\
\hline 01 July 2014 & $13: 33$ & 138.65 & 35.64 & 3.75 & SSW & $41.6 / 55$ \\
\hline 21 July 2014 & $14: 58$ & 138.67 & 35.65 & 4.25 & SW & $13.5 / 35$ \\
\hline 25 July 2014 & $16: 08$ & 138.69 & 35.66 & 4.75 & SW & $6.7 / 15$ \\
\hline 01 August 2014 & $19: 48$ & 138.63 & 35.62 & 4.75 & SW & $47.5 / 75$ \\
\hline 06 September 2014 & $17: 38$ & 138.45 & 35.64 & 2.25 & SW & $13.2 / 45$ \\
\hline
\end{tabular}



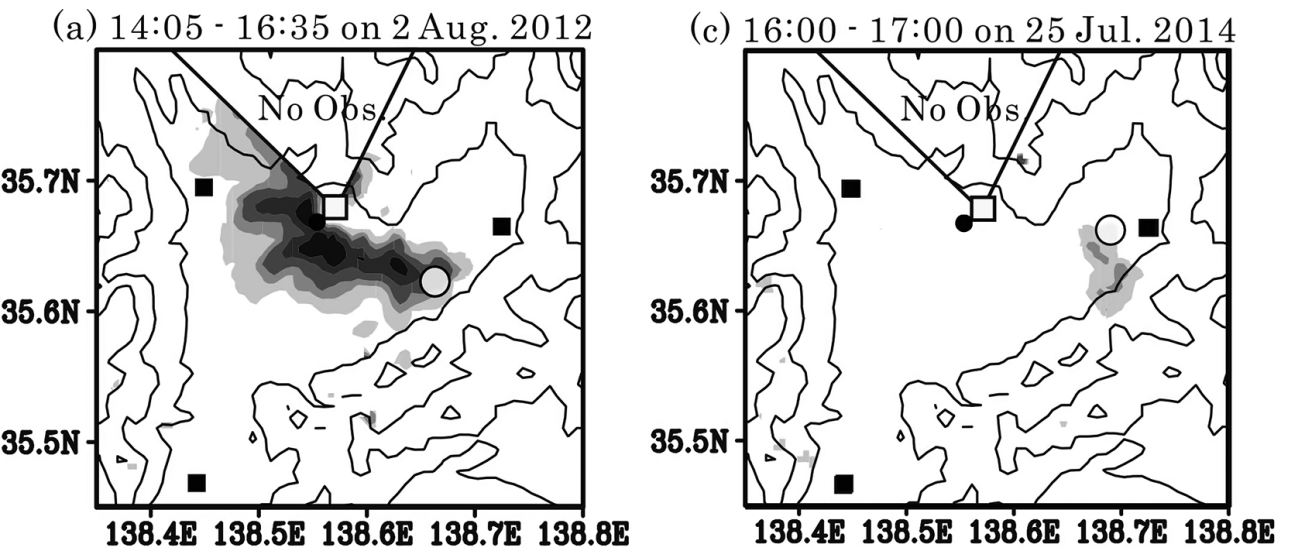

(b) 18:40 - 22:10 on 12 Sep. 2013

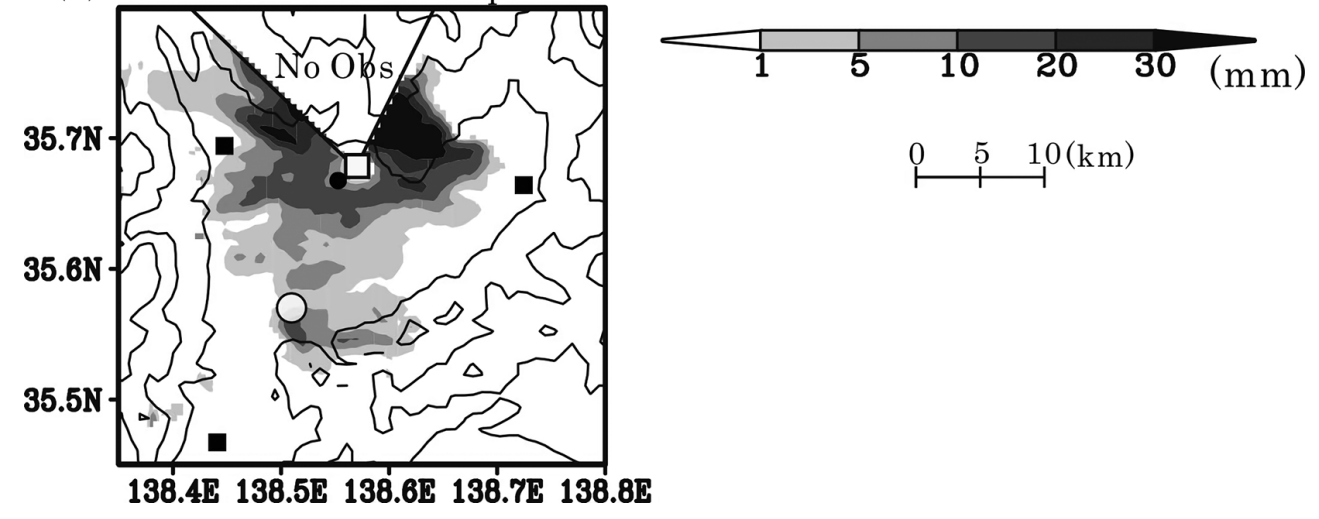

Fig. 3. Distributions of rainfall amount estimated (a) from 14:05 LST to 16:25 LST on 2 August 2012, (b) from 18:40 LST to 22:10 LST on 12 September 2013 and (c) from 16:00 LST to 17:00 LST on 25 July 2014 by the UYR observation. The white dot indicates the appearance point of the primary precipitating cell. The black contours indicate the $500 \mathrm{~m}$ elevations with beginning at $500 \mathrm{~m}$ ASL.

values of JMA-MSM". Here, the Kofu Basin is in the area surrounded by the black line in Fig. 1d. Sato and Kimura (2005) explained that the characteristics of the CII are almost similar to those of the Showalter stability index because the CII is proportional to the parcel buoyancy at $500 \mathrm{hPa}$ lifted from $800 \mathrm{hPa}$. Thus, a lower CII value indicates stratification between 800 and $500 \mathrm{hPa}$ close to the convective instability.

In all the cases, the CII over the Kofu Basin decreased after it reached a maximum at 09:00 LST (Fig. 4a). The minimum CII became negative in 9 cases and positive but less than $12.1 \mathrm{~K}$ in the other cases. From the minimum CII to the maximum CII in all cases, $\theta \mathrm{e}^{*}(500 \mathrm{hPa})$ increased or decreased slightly (Fig. $4 \mathrm{~b})$ and $\theta \mathrm{e}(800 \mathrm{hPa})$ increased (Fig. 4c). Thus, the small CII was caused by the increase in $\theta \mathrm{e}(800 \mathrm{hPa})$. Figure 5 shows the increase and decrease in $\theta$ e $(800$ $\mathrm{hPa}$ ) every three hours, where the values during that time interval are averaged in all cases. The standard deviation was 2.3 to $2.8 \mathrm{~K}$. The averaged $\theta \mathrm{e}(800 \mathrm{hPa})$ increased from 09:00 LST and 15:00 LST in almost all cases, and it increased from 15:00 LST and 18:00 LST in more than half of the cases, which decreased the CII over the Kofu Basin in the daytime.

\subsection{Surface temperature and wind}

Fujibe et al. (2002) reported that the wind patterns at the surface often form on the southern Kanto Plain, which contributes to the formation of horizontal convergence before the appearance of radar echoes. Thus, the wind patterns are maintained for a short time until just before a localized rainfall event. Kanda and Tsunoi (1995) reported that, when the Kofu Basin becomes hot in summer, a south component wind with relatively cool air passed along the valley connecting the Kofu Basin to the Suruga Bay side or an east 

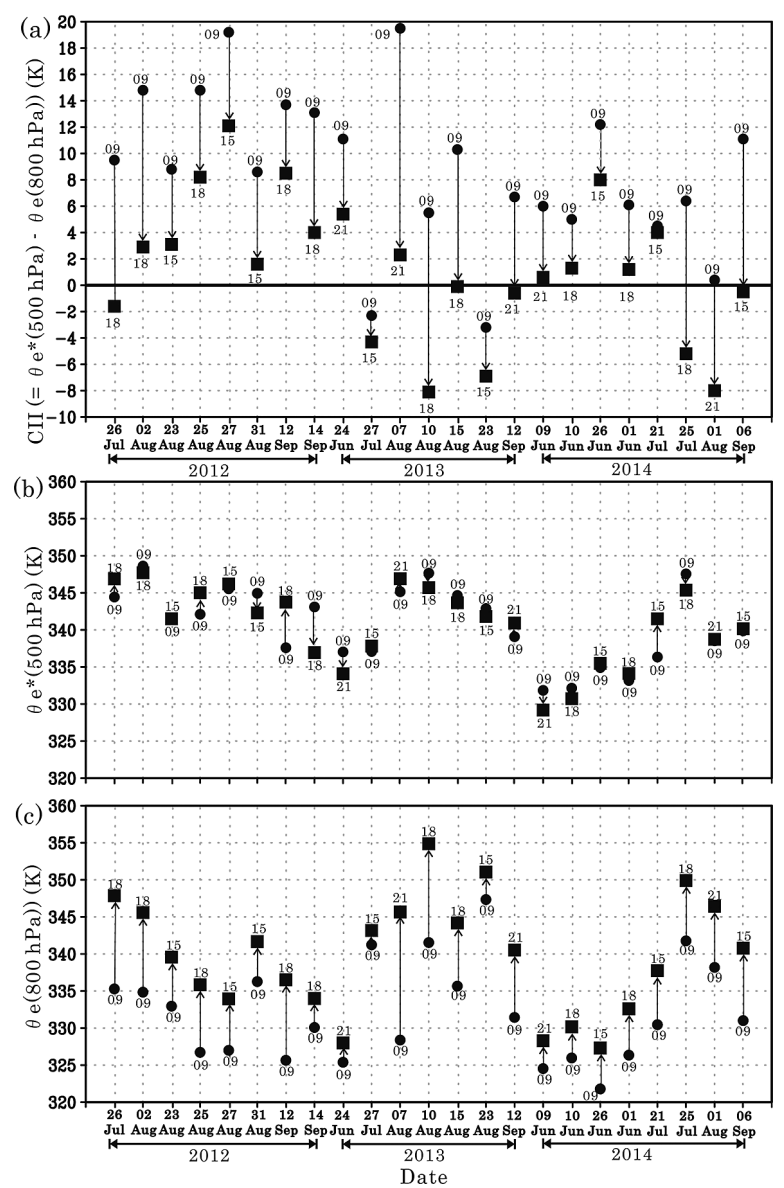

Fig. 4. (a) Minimum and maximum convective instability index, CII, (b) saturation equivalent potential temperature at $500 \mathrm{hPa}, \theta \mathrm{e}^{*}(500 \mathrm{hPa})$, and (c) equivalent potential temperature at 800 $\mathrm{hPa}, \theta \mathrm{e}(800 \mathrm{hPa})$, over the Kofu Basin (Fig. 1d) between 06:00 LST and 21:00 LST, as derived by the initial value of JMA-MSM in each case. The black circle and number indicate the maximum value and the time (LST); the black square and number indicate the minimum value and the time (LST).

component wind with relatively cool air often covered the Kofu Basin. To describe the surface conditions preceding a primary cellular echo, we investigated the average wind and temperature at mean sea level, with a lapse rate of $6.5^{\circ} \mathrm{C} \mathrm{km}^{-1}$, over $30 \mathrm{~min}$ prior to the appearance of a primary cellular echo at the surface meteorological observation points operated by the JMA.

Fifteen cases were dominated by SSW-ly wind in Kiriishi, SE-ly wind in Katsunuma, SE-ly wind in

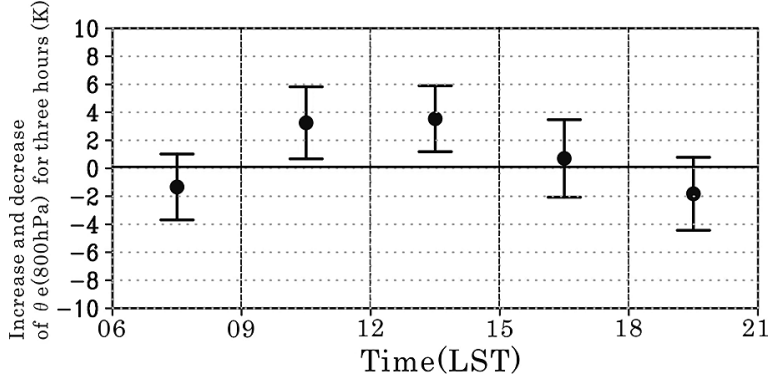

Fig. 5. Increase and decrease of $\theta e(800 \mathrm{hPa})$ every three hours over the Kofu Basin with the standard deviation (black dot and error bar) derived by the initial values of JMA-MSM. The values are averaged in all cases.

Nirasaki, and SW-ly or SSW-ly wind in Kofu (Fig. 6a, Table 2). The differences in temperature between Kofu and Kiriishi, between Kofu and Nirasaki, and between Kofu and Katsunuma were large, moderately large, and very small, respectively. In this situation, SSE-ly wind dominated in Nanbu and the temperature was almost similar to that at Kiriish, and NE-ly wind dominated in Ootsuki and the temperature was lower than that at Katsunuma. The appearance positions of the primary cellular echoes were concentrated in the central and eastern regions of the Kofu Basin. All but one of these cases began in the region with high temperature between the SSW-ly wind at Kofu and the SE-ly wind at Katsunuma.

Six cases were dominated by SSW-ly wind in Kiriishi, SE-ly wind in Katsunuma, SE-ly wind in Nirasaki, and SE-ly wind in Kofu (Fig. 6b, Table 2). The differences in temperature between Kofu and Kiriishi and between Kofu and Nirasaki were large and moderately large, respectively. The difference in temperature between Kofu and Katsunuma was reasonably small but was larger than in the preceding cases. In this situation, SSE-ly wind dominated in Nanbu and the temperature was almost similar to that at Kiriishi; NE-ly wind dominated in Ootsuki dominated and the temperature was lower than that in Katsunuma. The appearance positions of the primary cellular echoes were concentrated in the central region of the Kofu Basin. All but one of these cases began in the region between the SSW-ly wind at Kiriishi and the SE-ly wind at Kofu and Katsunuma.

An SSW-ly wind at Kiriishi and SE-ly wind at Katsunuma appeared in 2 cases (Fig. 6c). Under this condition, an SSE-ly wind appeared at Nanbu and the temperature was almost similar to that at Kiriishi. A 


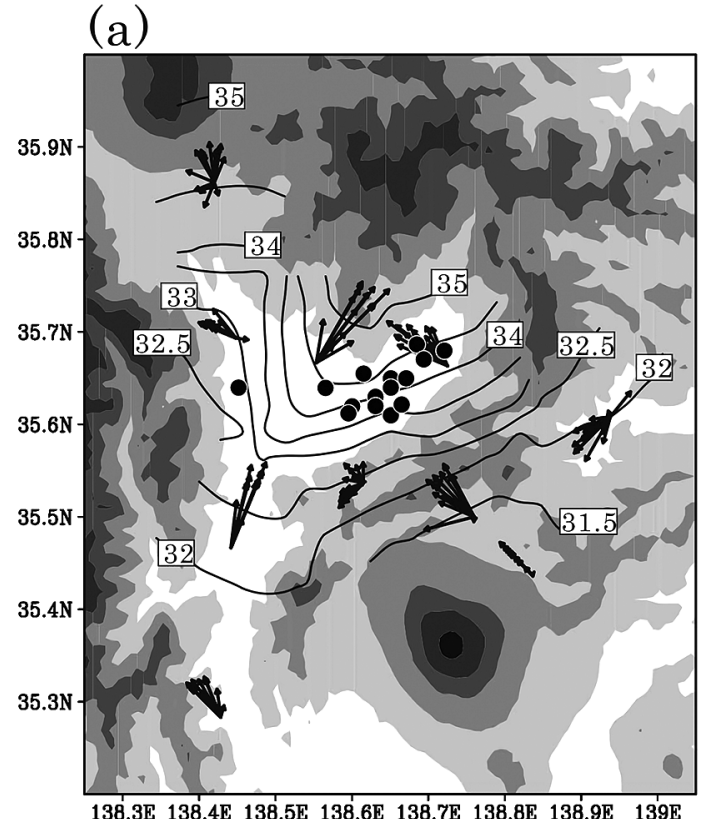

(c)

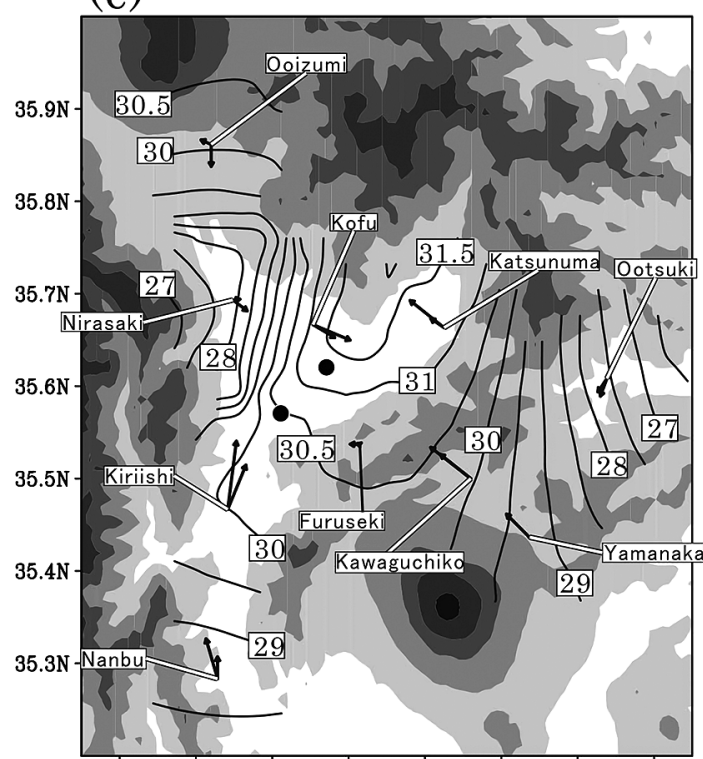

138.3E 138.4E 138.5E 138.6E 138.7E $138.8 \mathrm{E} \quad 138.9 \mathrm{E} \quad 139 \mathrm{E}$
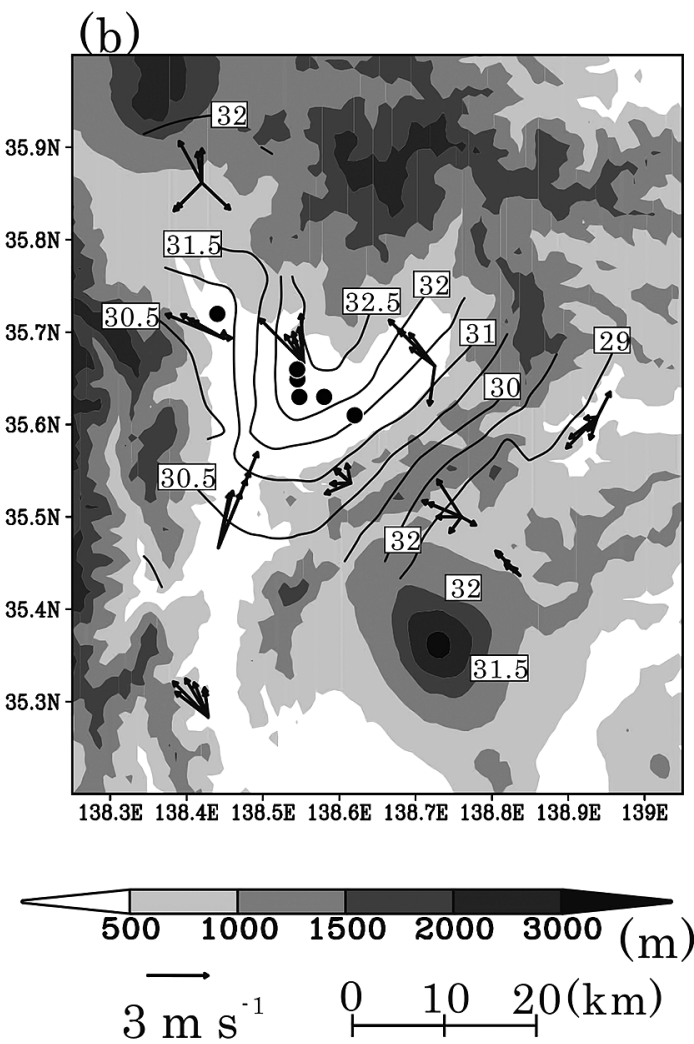

Fig. 6. Appearance points of primary cellular echoes (black dots) and averaged temperature at mean sea level with an assumed lapse rate of $6.5^{\circ} \mathrm{C} \mathrm{km}^{-1}$ (black contours) and averaged winds at observation points (black arrows). The temperature and wind were averaged for 30 min before the appearance time of the primary cellular echo. (a), (b) and (c) are the case of SW-ly to SSW-ly, SE-ly to SSE-ly, and WNWly winds at Kofu, respectively. The gray shaded areas indicate terrain.
NE-ly wind appeared at Ootsuki, and the temperature was lower than that at Katsunuma. However, a NW-ly wind and a WNW-ly wind appeared at Nirasaki and Kofu, respectively (Fig. 6c, Table 2), and the temperature at Nirasaki was lower than that at Kofu. The appearance positions of the primary cellular echoes were between Kofu and Kiriishi.

Primary cellular echoes appeared between SW-ly or SSW-ly winds and SE-ly wind in all cases. In this regard, the appearance position of the primary cellular echo in each case seemed to differ between the regions with SW-ly or SSW-ly winds and SE-ly wind, which conformed to the result of Sano et al. (2014).

\subsection{Atmospheric conditions preceding the appearance of a primary precipitating cell}

The characteristics of atmospheric conditions in the Kofu Basin preceding the appearance of primary precipitating cells under weak synoptic disturbance are as follows. SW-ly or SSW-ly winds in the western 
region of the basin passing through the valley between the Kofu Basin and the coastal region of Suruga Bay and SE-ly wind in the eastern region appeared, which brought air that was slightly cooler than that in the Kofu Basin. Under these conditions, the CII over the Kofu Basin became small associated with the increase in $\theta \mathrm{e}$ in the lower layer. Finally, a primary precipitating cell appeared at a large height over the region between the SW-ly or SSW-ly wind and the SE-ly wind at the surface. It is mentioned that this conditions often lead to a localized rainfall. From the above results, assuming that the formation of precipitating cells results in the concentration of water over the local region of the Kofu Basin, we suggest that the moisture was concentrated in the local region with horizontal convergence, where the horizontal convergence in the local region was formed by the SW-ly or SSW-ly winds and the SE-ly wind, and the moisture was transported to the Kofu Basin from the outside by the winds. The formation of the atmospheric conditions with the suggested moisture behaviors, however, remains a matter of speculation because of insufficient moisture observation in the Kofu Basin.

To discuss the process from the moisture transport to the formation of a primary precipitating cell in the Kofu Basin, we analyzed the changes in atmospheric conditions before the appearance of precipitating cells on the Kofu Basin in a case study on 25 July 2014. We consider this case to be typical of the precipitating cells that appear over the eastern region between the SW-ly wind and the SE-ly wind (Fig. 6a). The decrease in the CII from 09:00 LST to 18:00 LST (Fig. 4) was also representative, although the rainfall amount was small (Fig. 3c). In addition, for this case, meteorological observations of the pressure and relative humidity at the surface, GNSS-PWV, and other metrics, were conducted at several points in the Kofu Basin (Section 2). Thus, as one example of the atmospheric conditions leading to a localized rainfall on the Kofu Basin, we describe the results of this case study in the following section.

\section{Case study of the meteorological field preceding the appearance of precipitating cells on the Kofu Basin}

\subsection{Cloud and precipitation over the Kofu Basin under weak synoptic disturbance}

At 09:00 LST on 25 July 2014, a very weak pressure gradient between the anticyclones in the south and northwest at surface covered the Japanese archipelago (Fig. 7a). This condition was also maintained at 15:00 LST (not shown). At $500 \mathrm{hPa}$, air with a tem- perature from -3 to $-4.5^{\circ} \mathrm{C}$ and weak winds covered the analysis area at 09:00 LST (Fig. 7b), which didn't strongly contribute to the intensification of atmospheric instability and vertical wind shear. This condition was still maintained at 21:00 LST (not shown). Thus, the synoptic disturbances on the surface and at the upper layer were weak.

The cloud distribution under such a synoptic condition is shown in Fig. 8 as the horizontal distribution of albedo. The albedo was observed by MTSAT-2 for 30 min before the hour. Clouds covered Mts. Minobu, Mts. Tanzawa, and southern regions of Mt. Fuji and Mt. Kenashi at 09:00 LST. A small cloud appeared on Mt. Daibosatsu and the Chichibu mountains (Fig. 8a). Clouds covered the mountain regions surrounding the Kofu Basin until 15:00 LST (Figs. 8b, c) but appeared no rainfall area (not shown). Until 15:00 LST, no cloud area appeared over the Kofu Basin or the valleys connecting the coastal region of Suruga Bay to the Kofu Basin and connecting the Kanto Plain to the Kofu Basin via the mountain pass between Mts. Misaka and Mt. Daibosatsu. Then, a small cloud was detected in the eastern region $\left(138.66^{\circ} \mathrm{E}, 35.65^{\circ} \mathrm{N}\right)$ of the Kofu Basin at 16:00 LST (Fig. 8d), after which a convective precipitating system was observed there by the UYR.

Figure 9 shows the horizontal distribution of $Z_{H}$ at $5.25 \mathrm{~km} \mathrm{ASL}$, as observed by the UYR every 5 min from 15:58 to 17:03 LST. In this study, the echo system that consists of cellular echoes corresponds to a convective precipitating system consisting of precipitating cells. The appearance of a cell was defined as $Z_{H} \geq 30 \mathrm{dBZ}$ with a subsequent increase in $Z_{H}$. The horizontal distribution of $Z_{H}$ at $5.25 \mathrm{~km} \mathrm{ASL}$ indicates the behavior of the cellular echo for the period between appearance and development.

After the small cloud appeared in the eastern region, an echo system composed of cellular echoes appeared from 16:03 LST to 16:58 LST. In the eastern region of the Kofu Basin, a weak echo appeared at 16:03 LST (Fig. 9b). At 16:08 LST, cellular echo A, which is the primary cellular echo of the echo system, and cellular echo B (named cells A and B, respectively) appeared (Fig. 9c) and developed until 16:18 LST (Fig. 9d). Cellular echo C (cell C) appeared with $Z_{H} \geq 40 \mathrm{dBZ}$ at 16:13 LST (Fig. 9d). At 16:18 LST, cell C developed with $Z_{H} \geq 50 \mathrm{dBZ}$ (Fig. 9e); the area of cell C with $Z_{H} \geq 50 \mathrm{dBZ}$ was maintained until 16:28 LST (Figs. 9f, g). On the southern side of cell C, cellular echo D (cell D) appeared at 16:23 LST (Fig. 9f). Cell D developed and reached $Z_{H} \geq 50 \mathrm{dBZ}$ at 16:28 LST (Fig. $9 \mathrm{~g}$ ). On the western side of cells $\mathrm{C}$ and $\mathrm{D}$, a weak 
(a) Surface, 09:00 LST on 25 July 2014

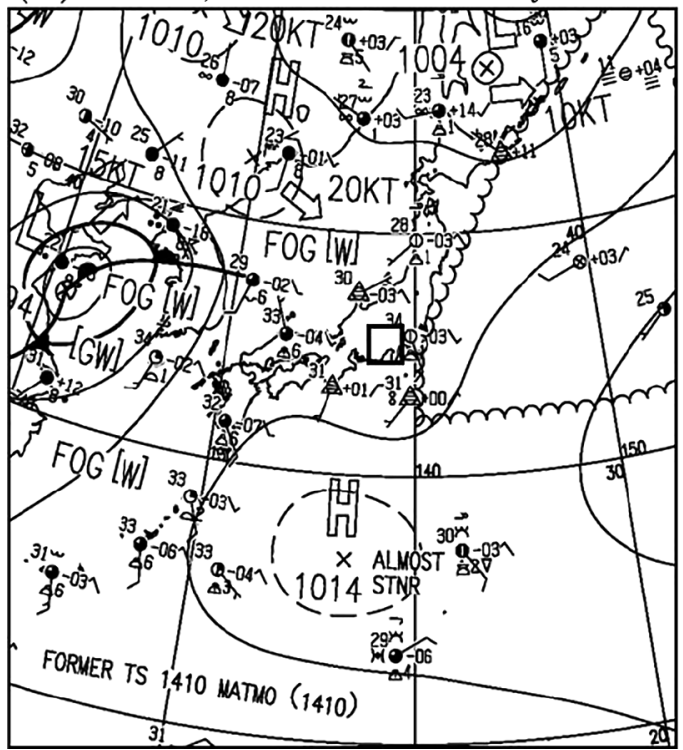

(b) 500 hPa, 09:00 LST on 25 July 2014

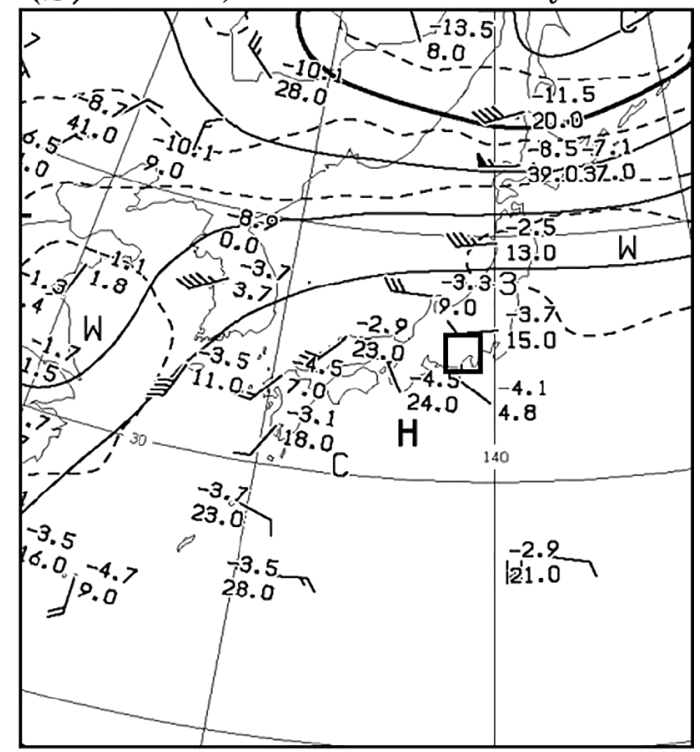

Fig. 7. Weather charts at (a) the surface and (b) the level of $500 \mathrm{hPa}$ at 09:00 LST on 25 July 2014. The rectangles indicate the analysis region. The source of the surface weather charts is the JMA publication.
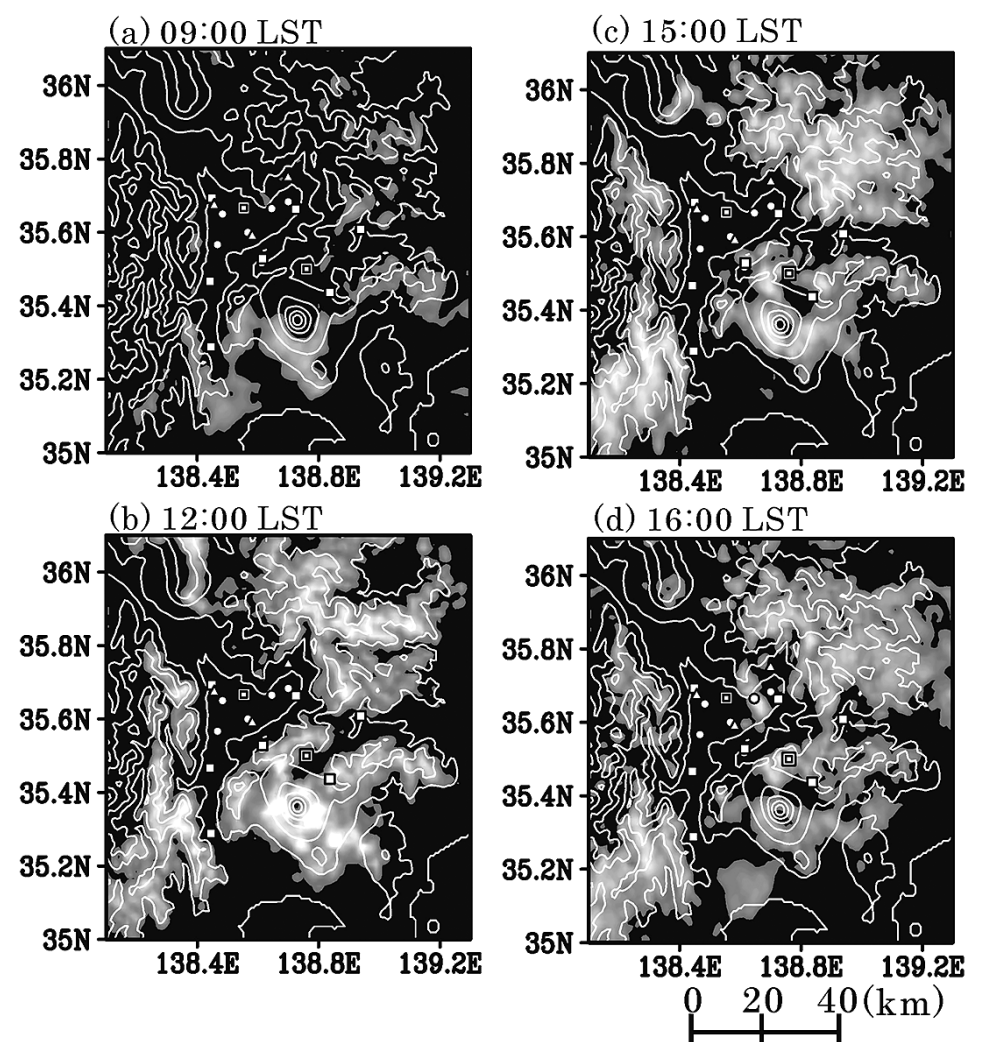

Fig. 8. MTSAT-2 visible image at (a) 09:00 LST, (b) 12:00 LST, (c) 15:00 LST and (d) 16:00 LST on 25 July 2014. The grey shaded areas indicate albedos derived from visible data. The thin white contours indicate terrains in $500 \mathrm{~m}$ intervals starting at $500 \mathrm{~m}$ ASL. The MTSAT2 data were sourced from the Weather Home, Kochi University. 

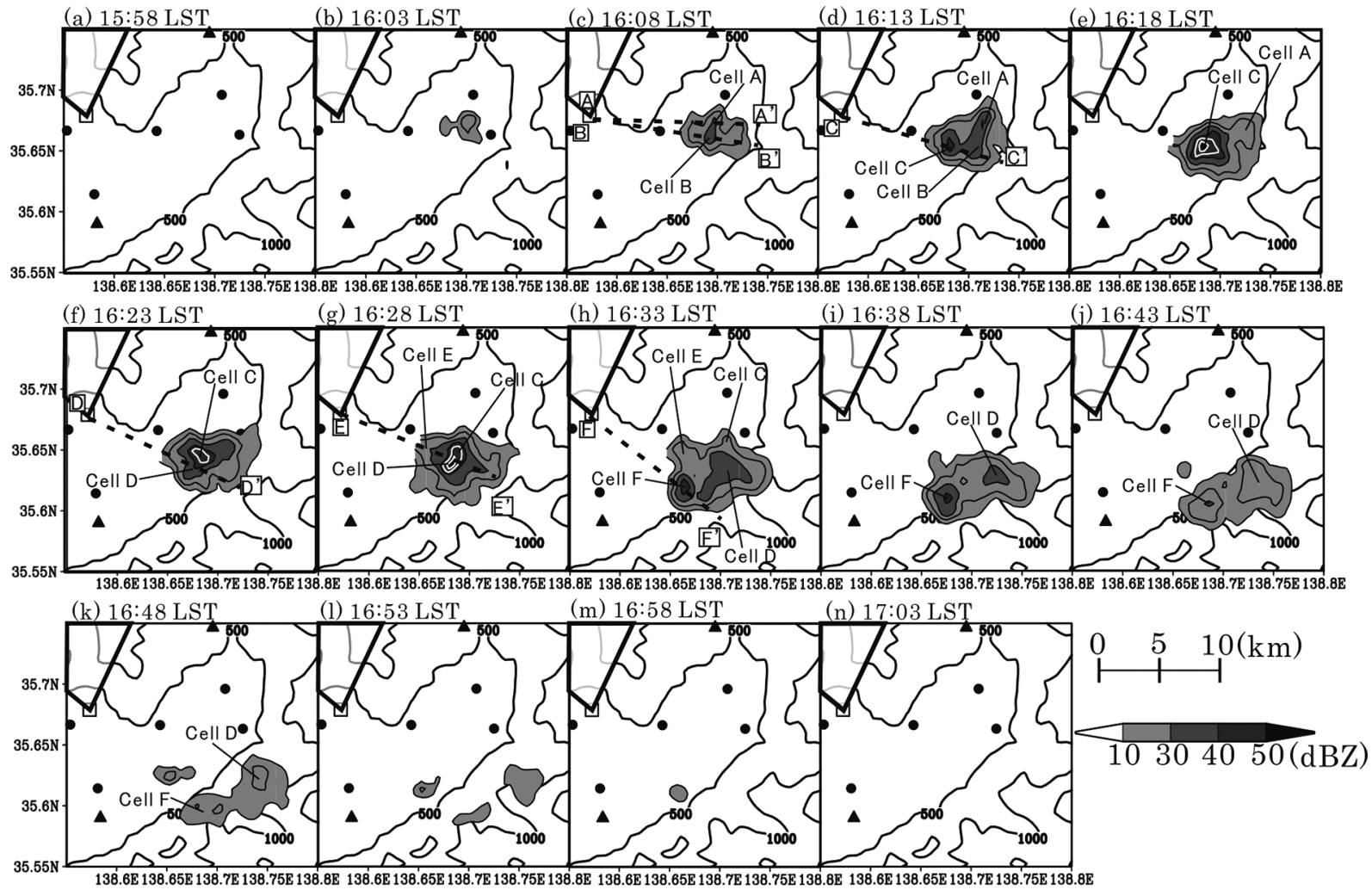

Fig. 9. Horizontal section of $Z_{H}$ at $5.25 \mathrm{~km} \mathrm{ASL}$, as observed by the UYR every 5 min from 15:58 LST to 17:03 LST. The black contours with shaded areas indicate $Z_{H}$ every $10 \mathrm{dBZ}$ up to $40 \mathrm{dBZ}$; the white contours with shaded areas indicate $Z_{H}$ every $5 \mathrm{dBZ}$ equal to more than $45 \mathrm{dBZ}$. The marks are the same as in Fig. 1c. The black contours indicate the terrains every $500 \mathrm{~m}$.

echo area appeared at 16:28 LST (Fig. 9g), which was the upper part of cellular echo $\mathrm{E}$ (cell E) with the $Z_{H}$ $\geq 30 \mathrm{dBZ}$ area at $3.25 \mathrm{~km}$ ASL (not shown). On the southwestern side of cell D, cellular echo F (cell F) appeared with $Z_{H} \geq 40 \mathrm{dBZ}$ at 16:33 LST (Fig. 9h).

To describe the appearance heights of the cellular echoes, Fig. 10 shows the vertical cross-section of $Z_{H}$ for each cellular echo at its first appearance. The horizontal axis (X-axis) in Fig. 10 indicates the distance from the UYR. Each vertical cross-section indicates the results of the first volume scans of the UYR. At 16:08 LST, the $Z_{H} \geq 30 \mathrm{dBZ}$ area of cell A appeared at $11 \mathrm{~km}$ from the UYR and 4 to $5 \mathrm{~km} \mathrm{ASL}$, and the $Z_{H} \geq 35 \mathrm{dBZ}$ area of cell B at $11.5 \mathrm{~km}$ from the UYR and 5.5 to $6.5 \mathrm{~km}$ ASL (Figs. 10a, b, respectively). At 16:13 LST, cell C with the $Z_{H} \geq 35 \mathrm{dBZ}$ area appeared at $10.5 \mathrm{~km}$ from the UYR and 4.5 to $6 \mathrm{~km}$ ASL, with the $Z_{H} \geq 40 \mathrm{dBZ}$ area appearing at $5.5 \mathrm{~km}$ ASL (Fig. $10 \mathrm{c})$. Cell D with the $Z_{H} \geq 35 \mathrm{dBZ}$ area at $11 \mathrm{~km}$ from the UYR and 4 to $6.5 \mathrm{~km}$ ASL appeared at 16:23 LST
(Fig. 10d). Cell E with the $Z_{H} \geq 35 \mathrm{dBZ}$ area appeared at $9 \mathrm{~km}$ from the UYR and 4 to $5 \mathrm{~km} \mathrm{ASL}$ at $16: 28$ LST (Fig. 10e). Finally, cell F appeared at $11 \mathrm{~km}$ on the X-axis and 5 to $7 \mathrm{~km} \mathrm{ASL}$ with the $Z_{H} \geq 40 \mathrm{dBZ}$ area at $6 \mathrm{~km}$ ASL (Fig. 10f).

Using dual-polarimetric radar observation, previous studies reported that the initial positive $Z_{D R}$ column at the edge of an initial cellular echo was closely associated with an updraft (Brandes et al. 1995; Kumjian et al. 2014). Figure 11 shows the vertical distributions of $Z_{D R}$ and $D V$ for cellular echoes at their initial appearance observed by the UYR. Herein, a positive (negative) $D V$ indicates radial velocity moving away from (moving toward) the UYR. In each cell, the positive $Z_{D R}$ column extended toward the cell's cores along from the lower layer at the echo edge. Then, along the positive $Z_{D R}$ column, the negative $D V$ became positive from the lower part to the upper part. These results support that the initial appearance of cellular echoes at high altitudes in the small-cloud region were caused 
(a) 16:08 LST

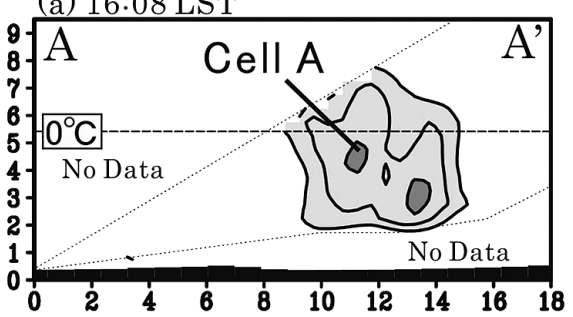

(b) 16:08 LST

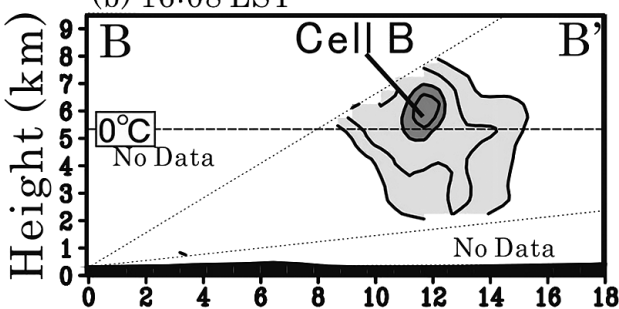

(c) $16: 13 \mathrm{LST}$

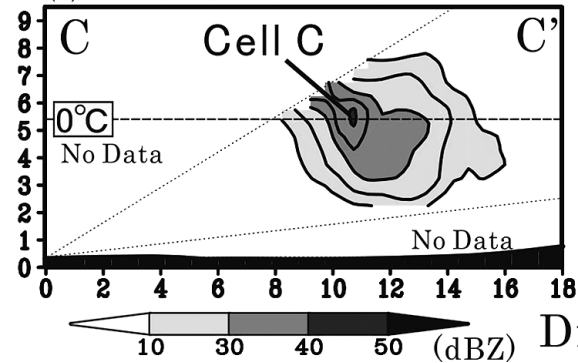

(d) 16:23 LST

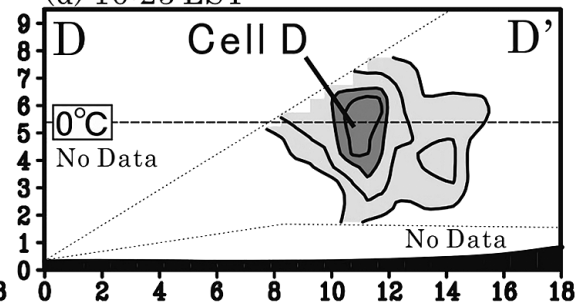

(e) 16:28 LST

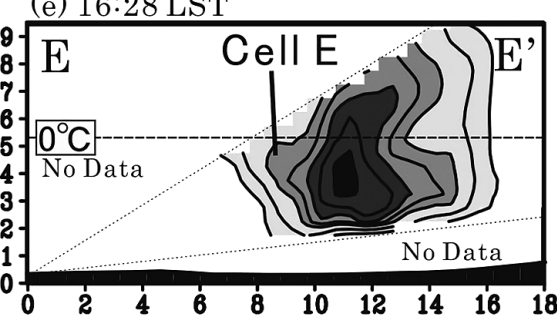

(f) $16: 33 \mathrm{LST}$

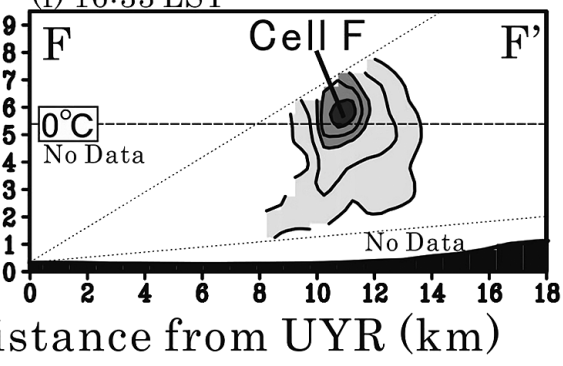

Fig. 10. Vertical sections of $Z_{H}$ (gray shaded areas with black contours) of cells $\mathrm{A}, \mathrm{B}, \mathrm{C}, \mathrm{D}, \mathrm{E}$, and $\mathrm{F}$ along lines A-A', B-B', C-C', D-D', E-E' and F-F' in Fig. 9. The 0-km mark on the horizontal axis is the position of the UYR. The black shaded region at the lowest part indicates the terrain. The black dashed line indicates the level of $0^{\circ} \mathrm{C}$ derived by the initial value of JMA-MSM at 15:00 LST on 25 July 2014.

by intensified cumulus updraft.

The appearance of the cloud and the echo system on the Kofu Basin under weak synoptic conditions suggests the existence of unstable conditions over the Kofu Basin and the trigger of the cloud and the echo system on the Kofu Basin. Furthermore, the appearance of the cellular echoes at high altitudes reflects the results of the moisture concentration and moisture uplift in the local region.

\subsection{Meteorological field on the Kofu Basin preceding the appearance of an echo system}

To describe the environmental conditions associated with these echo systems, the vertical profile of the atmosphere over the Kofu Basin was investigated using the initial values of JMA-MSM. Figure 12 shows the vertical profiles of temperature, dew-point temperature, u- and v-component velocities, and geo-potential height at Hamamatsu, as derived from the initial values of JMA-MSM. Sounding observation at 09:00 LST was used to confirm the accuracy of the initial values of JMA-MSM. The vertical profiles of temperature, dew-point temperature, and wind speed derived from the initial values of JMA-MSM at Hamamatsu were almost similar to those of the sounding observation with slight differences. After that, we discuss the upper-air condition over the Kofu Basin on the basis of the initial values of JMA-MSM data.

The vertical profiles of the atmosphere over the Kofu Basin derived from the initial values of JMAMSM at 09:00 and 15:00 LST are shown in Fig. 13a. The altitude at $0^{\circ} \mathrm{C}$ at 09:00 and 15:00 LST was 5.4 $\mathrm{km}$ ASL. The increase in $\theta \mathrm{e}$ was larger below $700 \mathrm{hPa}$ than above $700 \mathrm{hPa}$. The differences in $\theta \mathrm{e}^{*}(500 \mathrm{hPa})$ and $\theta \mathrm{e}(800 \mathrm{hPa})$ at 09:00 and 15:00 LST were 6.4 and $-2 \mathrm{~K}$, respectively. The atmospheric conditions over the Kofu Basin became unstable because of the increase in $\theta \mathrm{e}$ in the lower layer. At 15:00 LST, the 

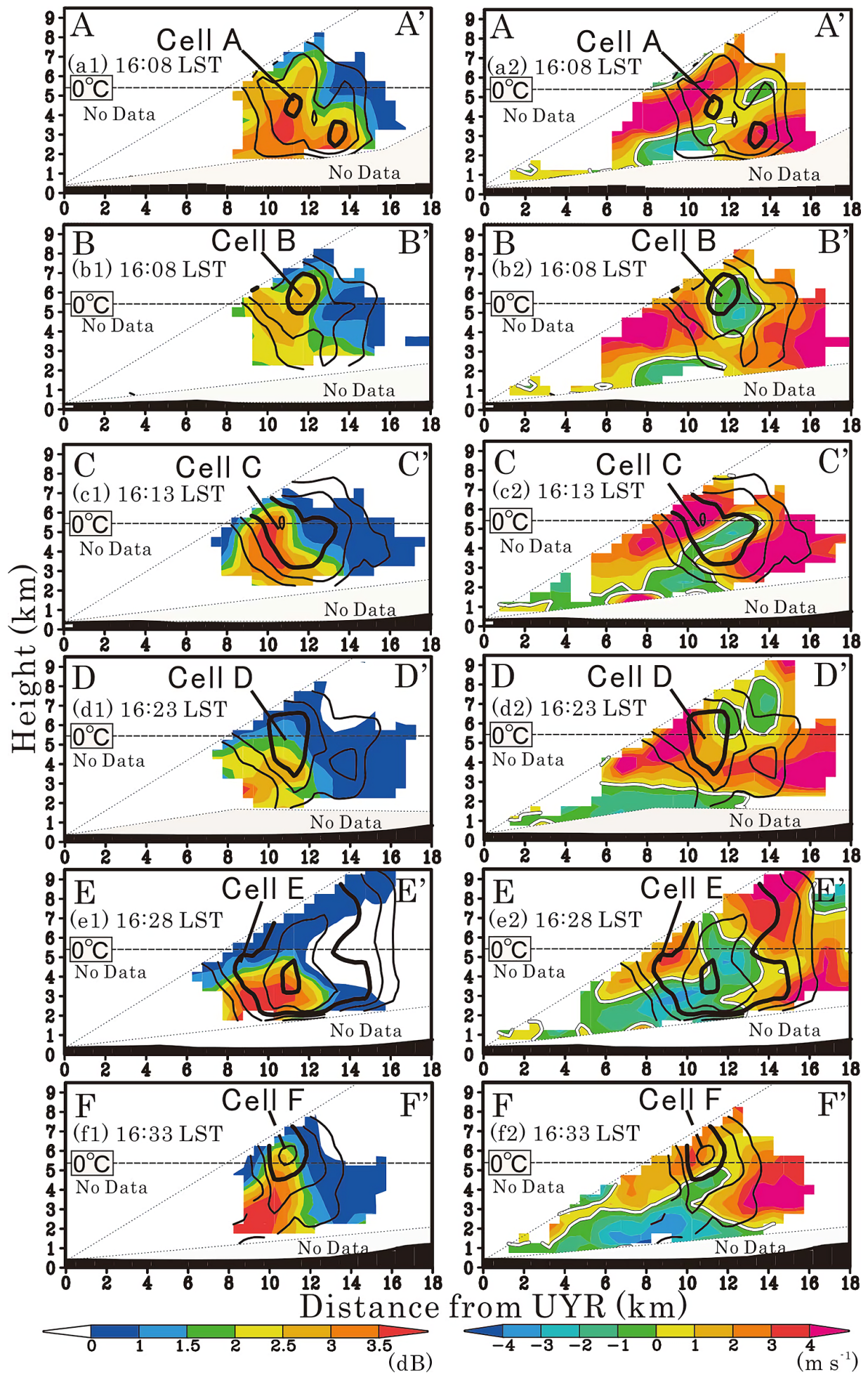

Fig. 11. Vertical sections of $Z_{D R}$ (color shaded areas) with $Z_{H}$ (black contours, from $10 \mathrm{dBZ}$ every $10 \mathrm{dBZ}$ ) and $D V$ (color shaded areas) with $Z_{H}$ (black contours, from $10 \mathrm{dBZ}$ every $10 \mathrm{dBZ}$ ) of cells $\mathrm{A}, \mathrm{B}, \mathrm{C}, \mathrm{D}, \mathrm{E}$, and $\mathrm{F}$ along lines A-A', B-B', C-C', D-D', E-E' and F-F' in Fig. 9. The 0-km mark on the horizontal axis is the position of the UYR. Positive (Negative) $D V$ indicates a radial velocity moving away from (moving toward) the UYR. 

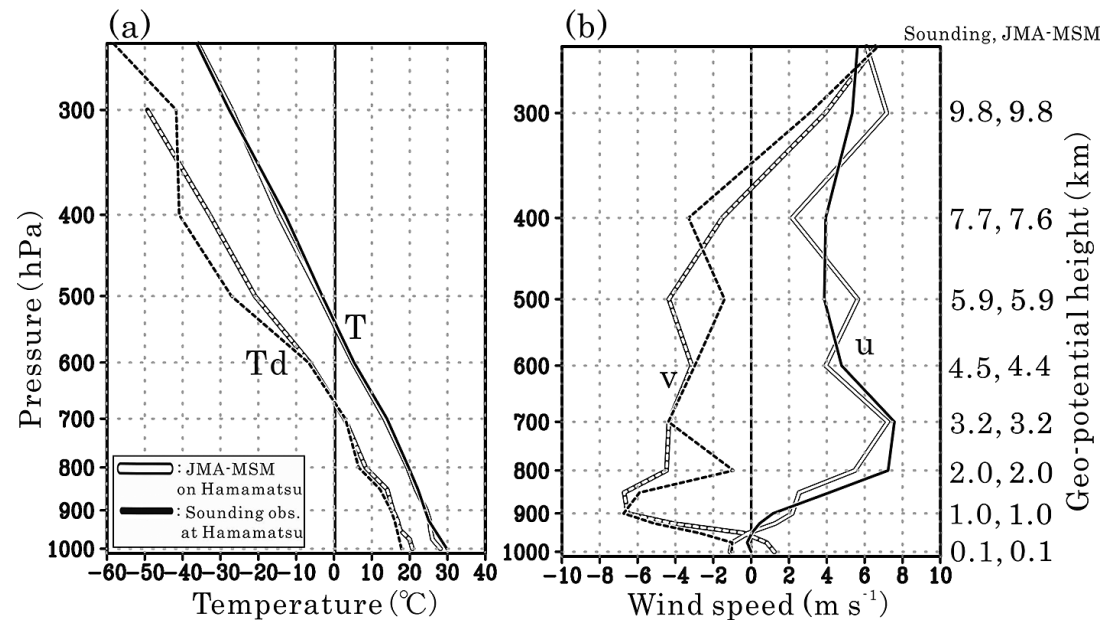

Fig. 12. Vertical profiles of (a) temperature (solid line) and dew-point temperature (dashed line) and (b) horizontal wind speeds (u-component: solid line, v-component: dashed line) with geo-potential height observed by the sounding at Hamamatsu (white lines) and derived by the initial values of JMA-MSM on Hamamatsu (black lines) at 09:00 LST on 25 July 2014.
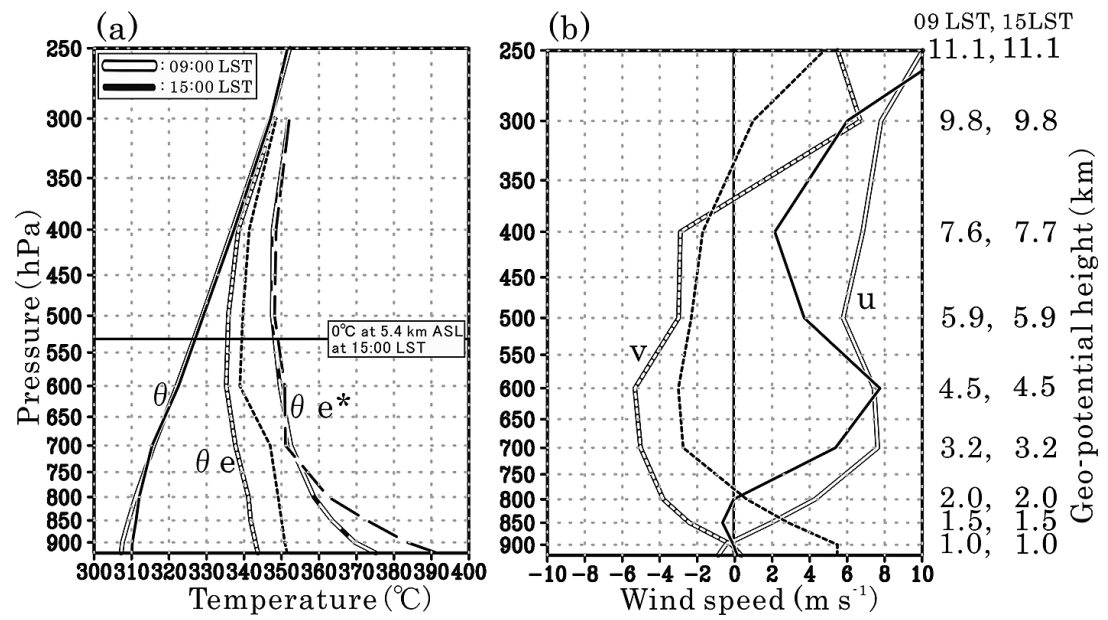

Fig. 13. Vertical profiles of (a) potential temperature $(\theta$; solid line), equivalent potential temperature $(\theta e$; shortdashed line), saturation potential temperature $\left(\theta \mathrm{e}^{*}\right.$; long-dashed line) and (b) horizontal wind speeds (u-component: solid line; v-component: dashed line) with geo-potential height derived by the initial value of JMA-MSM on the Kofu Basin (Fig. 1d) at 09:00 LST (white lines) and 15:00 LST (black lines) on 25 July 2014.

vertically constant $\theta$ e lines from $\theta e$ at 800 and 900 $\mathrm{hPa}$, near the surface, intersected with the $\theta \mathrm{e}^{*}$ lines at 700 and $570 \mathrm{hPa}$, respectively. The level of free convection (LFC) was between 3.1 and $4.9 \mathrm{~km}$ ASL. Here, from the sounding observation at Hamamatsu at 09:00 LST, the lifting condensation level (LCL) and LFC were calculated as $1.7 \mathrm{~km}$ ASL and $4.4 \mathrm{~km}$ ASL, respectively, when a parcel at $45 \mathrm{~m}$ ASL (the lowest height) was lifted. A strong trigger at the lower layer was necessary to cause wet convection because of the high LCL and LFC.

The WNW-ly and NW-ly winds were maintained between 700 and $400 \mathrm{hPa}$ from 09:00 to 15:00 LST. The wind speed at 15:00 LST was 2.7 to $8.3 \mathrm{~m} \mathrm{~s}^{-1}$. Below $800 \mathrm{hPa}$, weak easterly wind at $925 \mathrm{hPa}$ changed with altitude to a strong NW-ly wind at 09:00 LST (Fig. 13b). At 15:00 LST, a strong southerly wind at $925 \mathrm{hPa}$ changed to a very weak easterly wind with 

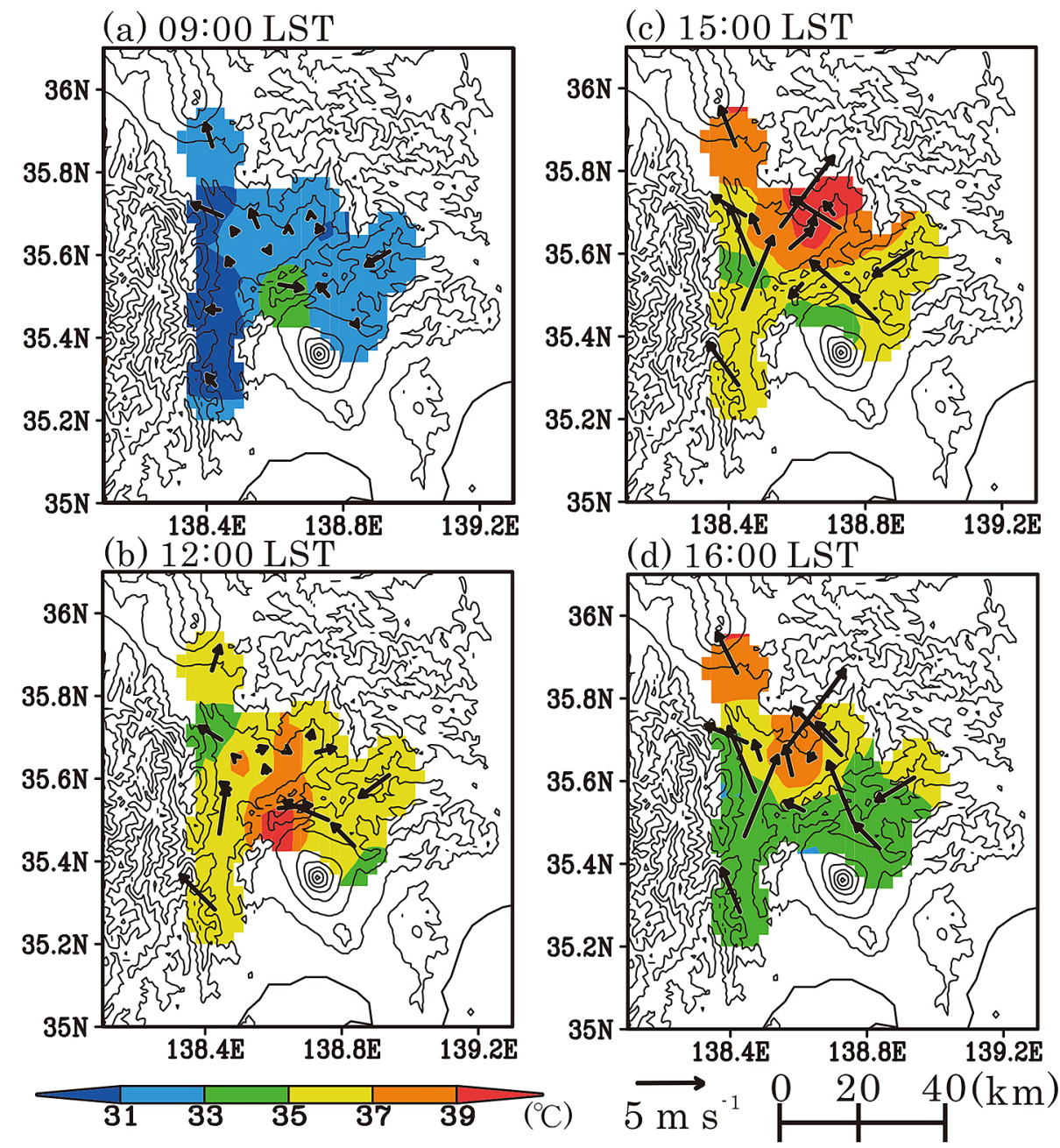

Fig. 14. Temperature at mean sea level with assumed lapse rate of $6.5^{\circ} \mathrm{C} \mathrm{km}^{-1}$ at surface meteorological observation points and winds at surface observation points at (a) 09:00 LST, (b) 12:00 LST, (c) 15:00 LST and (d) 16:00 LST on 25 July 2014. The color shaded areas indicate the temperature derived by the surface observations. The arrows indicate wind speed and direction at each observation point. The black contours indicate the $500 \mathrm{~m}$ elevations from $500 \mathrm{~m}$ ASL.

increasing altitude. Winds over the Kofu Basin below the level of $800 \mathrm{hPa}$ became weak in the daytime; southerly wind near the surface became strong.

Figure 14 shows the surface winds and temperature at mean sea level as a function of the lapse rate of 6.5 ${ }^{\circ} \mathrm{C} \mathrm{km}^{-1}$ on the Kofu Basin and the valleys connecting it to the coastal region of Suruga Bay and to the Kanto Plain. Here, wind speeds at Kamihatta, Kosaiminami, Shimoimai, and Atoyashiki by NTT DOCOMO, Inc. and Kasugai by University of Yamanashi tend to be weaker than those at Kofu, Nirasaki, Katsunuma, Kiriishi, Furuseki, Ooizumi, Nanbu, Ootsuki, Yamanaka, and Kawaguchiko by the JMA. This is partly attrib- utable to the lower elevation of wind observations by NTT DOCOMO, Inc., and University of Yamanashi, compared to are lower than those of the JMA. On the other hand, the variations of temperature and wind direction associated with the changing meteorological phenomena differed only slightly between the observations. For the case study, we used wind at the surface without the level correction.

At 09:00 LST, there were weak winds blowing toward the mountains and vagrant winds with a high temperature (Fig. 14a). Vagrant weak winds at the surface in the Kofu Basin were maintained at 12:00 LST (Fig. 14b) and the temperature increased until 

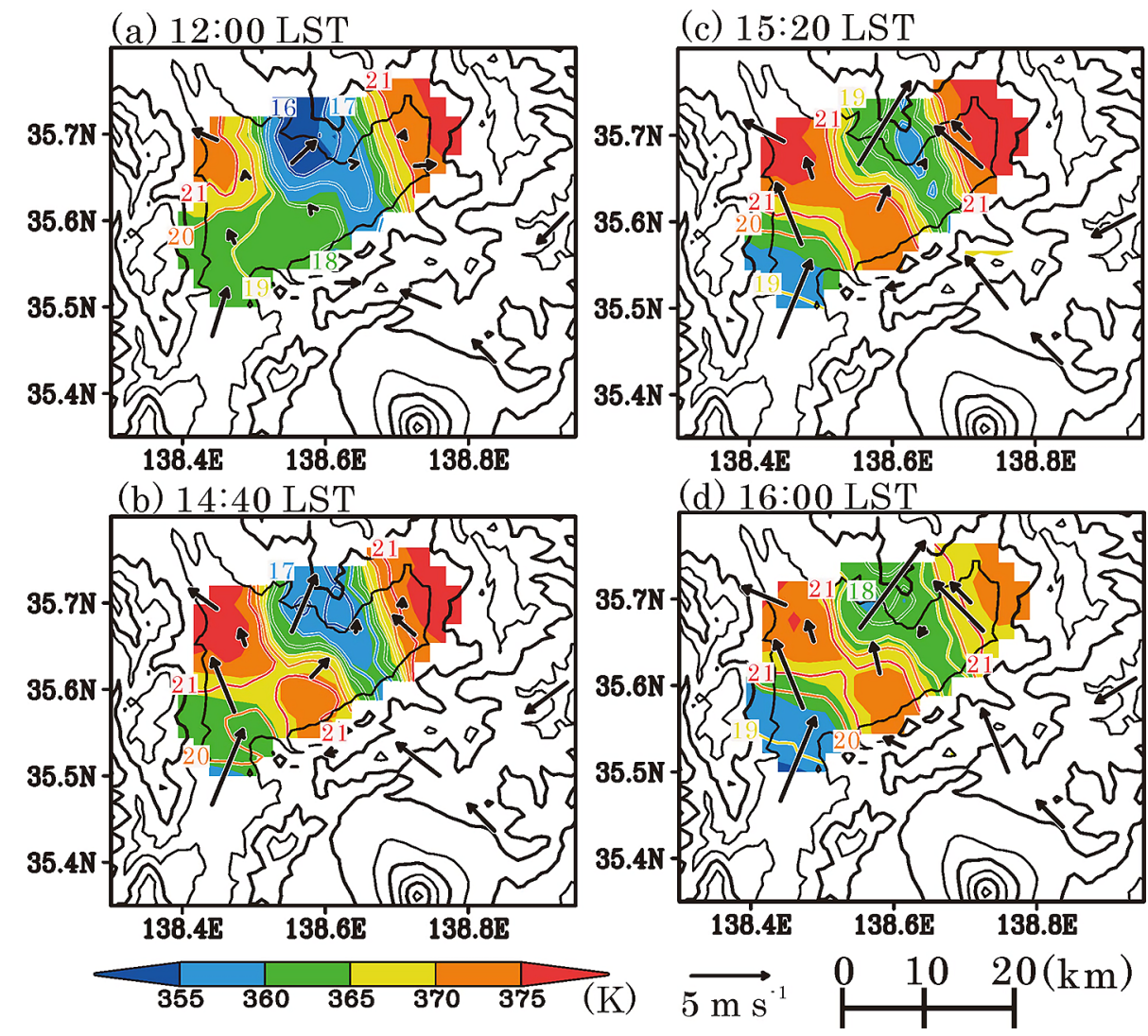

Fig. 15. Equivalent potential temperature $(\theta \mathrm{e})$, water vapor mixing ratio $(Q v)$ and winds at surface observation points in the Kofu Basin at (a) 12:00 LST, (b) 14:40 LST, (c) 15:20 LST and (d) 16:00 LST on 25 July 2014. The color shaded areas and contours indicate the $\theta e$ and $Q_{V}$ values derived from the surface observations at Kofu, Kamihatta, Kosaiminami, Shimoimai, Atoyashiki and Kasugai (Fig. 1c). The arrows indicate wind speed and direction at each observation point. The black contours indicate the $500 \mathrm{~m}$ elevations from $500 \mathrm{~m}$ ASL.

15:00 LST (Fig. 14c). In the valley connecting to the coastal region of Suruga Bay, SE-ly and SW-ly winds appeared with increasing temperatures at 12:00 LST (Fig. 14b). Then, SE-ly and SW-ly winds respectively appeared at the observation points in the western and central regions of the Kofu Basin at 15:00 LST (Fig. 14c). The temperatures in the regions with the SE-ly and SW-ly winds decreased until 16:00 LST (Fig. $14 d)$. In the valley connecting to the Kanto Plain, a NE-ly wind developed from 12:00 LST and the temperature decreased from 15:00 LST. Then, a SE-ly wind developed in the eastern region of the Kofu Basin at 15:00 LST, and the temperature began decreasing at 16:00 LST. Thus, the pattern of the SW-ly wind in the western and central regions and the SE-ly wind in the eastern region formed on the Kofu Basin, which contributed to the formation of horizontal convergence at the surface in the central and eastern regions of the Kofu Basin.

Figure 15 shows the equivalent potential temperature $(\theta \mathrm{e})$, water vapor mixing ratio $(Q v)$, and surface wind observation points in the Kofu Basin. At 12:00 LST, a weak vagrant wind appeared in the central region of the Kofu Basin with low $\theta \mathrm{e}$ and $Q_{V}$ (Fig. 15a). At Nirasaki and Katsunuma, winds blew toward the mountains.

At 14:40 LST, SE-ly and SW-ly winds with high $\theta$ e and $Q_{V}$ appeared in the western and central regions and SE-ly and SW-ly winds with low $\theta$ e and $Q V$ appeared at the mouth of the valley connected to the coastal region of Suruga Bay (Fig. 15b). In the eastern region of the Kofu Basin, a SE-ly wind began to appear (Fig. 15b), which developed with high $\theta$ e and $Q_{V}$ at 15:20 LST (Fig. 15c). Thus, the $\theta$ e and $Q_{V}$ in the central region of the Kofu Basin increased with this weak wind until 16:00 LST associated with the pattern 
of the SW-ly wind in the western region and the SE-ly wind in the eastern region (Fig. 15d). This changed the atmospheric conditions at the surface from heat and aridity to moderate heat and humidity.

Figure 16 shows the temporal variations of GNSSPWV at Nakamichi, Nirasaki, and Makioka in the central, northwestern, and northeastern regions of the Kofu Basin, respectively. The GNSS-PWVs at Nirasaki, Makioka, and Nakamichi decreased slightly until 11:40, 11:50, and 12:00 LST, respectively. Then, the GNSS-PWVs at Nirasaki and Makioka increased gradually until 16:00 LST. On the other hand, the GNSS-PWV at Nakamichi increased abruptly from 14:30 LST, when the GNSS-PWV was $44 \mathrm{~mm}$. It reached $54 \mathrm{~mm}$ by 15:30 LST, which corresponded to the increases in $\theta \mathrm{e}$ and $Q v$ at the surface and the formation of the surface wind pattern. This suggests that the vertical humidification over the Kofu Basin occurred before the appearance of the cloud and the echo system.

\subsection{Atmospheric conditions on the Kofu Basin analyzed by JMA-MANAL based on observations}

The observation results suggest that the atmospheric conditions that connected to the occurrence of wet convection formed in the Kofu Basin under weak synoptic disturbance. To describe such atmospheric conditions, we analyzed JMA-MANAL data with a horizontal resolution of $5 \mathrm{~km}$, which can resolve local wind in the meso- $\beta$ scale, on the basis of the observation results.

At $900 \mathrm{hPa}$ (a geo-potential height of about 1,018 $\mathrm{m})$, a high $\theta$ with weak winds and a somewhat lower QV appeared on the Kofu Basin at 12:00 LST (Fig. 17a). The $\theta$ value in the Kofu Basin was higher than that outside the basin. In the valley connecting the coastal region of Suruga Bay to the Kofu Basin, the south-component wind was dominant with a $\theta$ gradient that increased toward the Kofu Basin and a large $Q_{V}$. Then, in the valley connecting to the Kanto Plain to the Kofu Basin, east-component wind with the $\theta$ gradient increasing toward the Kofu Basin and somewhat higher $Q_{V}$ blew in. As compared with the observation result, this condition is almost similar to that at the surface (300 to $600 \mathrm{~m}$ ASL in Fig. 1d) at 12:00 LST (Fig. 14b) although the appearance of SE-ly wind on the eastern side in JMA-MANAL was early.

The top of the convective boundary layer that developed over the Kofu Basin reached a height of $800 \mathrm{hPa}$ (a geo-potential height of about 1,988 m) with a high $\theta$ in the convective boundary layer, which

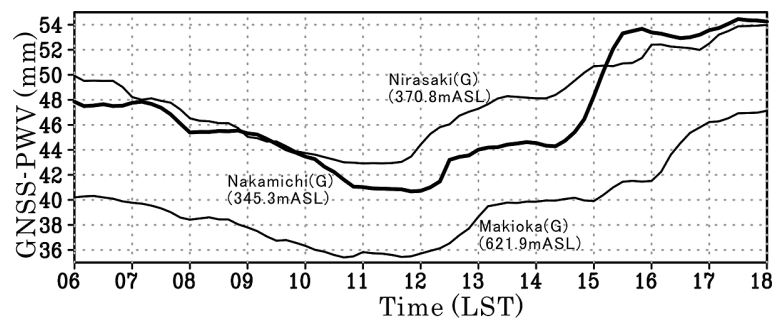

Fig. 16. Temporal variations in precipitable water vapor derived from GNSS observation (GNSSPWV) at Nakamichi, Nirasaki, and Makioka from 06:00 LST to 18:00 LST on 25 July 2014.

was higher than the mountain passes in the valleys connecting the coastal region of Suruga Bay, and the Kanto Plain. In the valley connected to the coastal region of Suruga Bay, the south-component wind with a large $Q v$ and $\theta$ gradient below a height of 850 $\mathrm{hPa}$ passed over the small mountain pass (Fig. 17b). Furthermore, the east-component wind blowing in the valley connected to the Kanto Plain below a height of $800 \mathrm{hPa}$ passed over the mountain pass with a large $Q_{V}$ and $\theta$ gradient (Fig. 17c). The analysis results support the observation result that the SW-ly wind and the SE-ly wind blew from the outside and caused the increase in $Q_{V}$ and the decrease in temperature in the Kofu Basin (Figs. 14, 15).

Figure $18 \mathrm{a}$ shows the $\theta \mathrm{e}$, winds, and horizontal divergence at $900 \mathrm{hPa}$ as derived by JMA-MANAL at 15:00 LST. The $\theta$ e distribution and the wind distribution in JMA-MANAL at 15:00 LST were almost similar to those in the surface observation at 15:20 LST and 16:00 LST (Figs. 15c, d) although the difference in the $\theta \mathrm{e}$ value between JMA-MANAL and the observations was large. Thus, the low $\theta \mathrm{e}$ in the eastern region in JMA-MANAL at 15:00 LST corresponds roughly to the decrease in $\theta \mathrm{e}$ in the surface observation at 15:20 LST and 16:00 LST. The horizontal convergence was formed in the central and eastern regions of the Kofu Basin by the south-component wind from the valley connected to the coastal region of Suruga Bay and the SE-ly wind from the valley connected to the Kanto Plain. Then, a large $\theta \mathrm{e}$ appeared at the strong horizontal convergence.

As shown in the vertical section at line B-B' in Fig. $18 \mathrm{a}, \theta \mathrm{e}$ was large in the Kofu Basin below 700 $\mathrm{hPa}$ (Fig. 18b). The $\theta \mathrm{e}$ distribution in the central and eastern regions shows a convex upward trend with horizontal convergence at the lower (upper) part and divergence at the upper part. Along the convex-like 

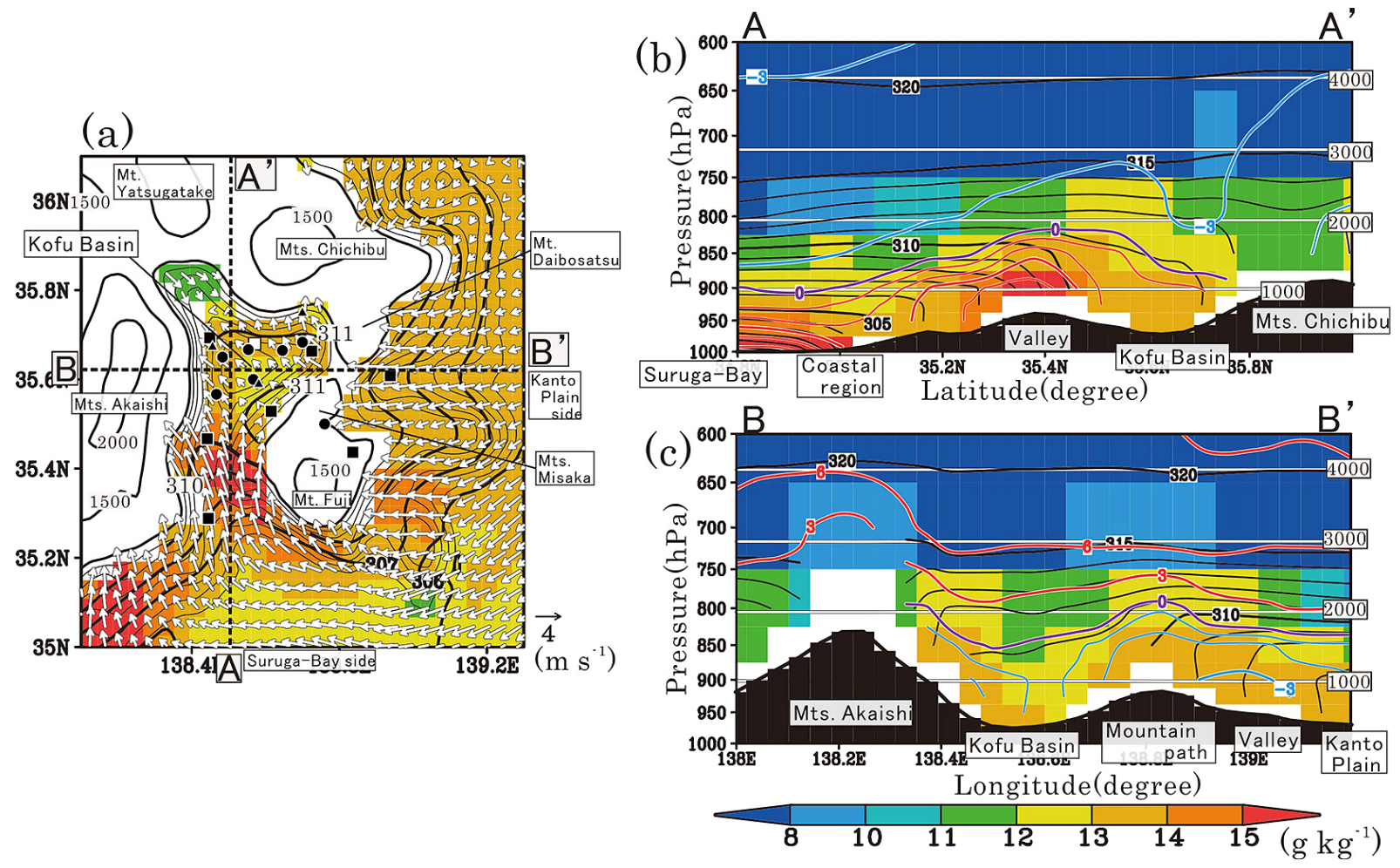

Fig. 17. (a) Horizontal section of potential temperature $(\theta)$, water vapor mixing ratio $(Q v)$ and winds at $900 \mathrm{hPa}$, and vertical sections of $\theta, Q v$, geo-potential height, and horizontal velocities at lines A-A' (b) and B-B' (c) in (a), as derived from JMA-MANAL at 12:00 LST. The color shaded areas indicate $Q v$. The thick black contours indicate $\theta$ every $1 \mathrm{~K}$ to $315 \mathrm{~K}$ and every $5 \mathrm{~K}$ above $315 \mathrm{~K}$. The white arrows in (a) indicate winds. The thin black contours in (a) indicate terrain using JMA-MANAL every $100 \mathrm{~m}$ (Fig. 1d). The white contours in (b) and (c) indicate geo-potential height (unit: $\mathrm{m}$ ). The red and blue contours in (b) indicate positive velocities (left to right in the section) every $1 \mathrm{~m} \mathrm{~s}^{-1}$ and negative velocities (right to left in the section) every $3 \mathrm{~m} \mathrm{~s}^{-1}$, with 0 $\mathrm{m} \mathrm{s}^{-1}$ (purple contours). These magnitudes are reversed in (c). The black shaded areas in (b) and (c) indicate the terrain identified using JMA-MANAL (Fig. 1d).

distribution of $\theta e, Q v$ increased after 12:00 LST with convergence with strong winds below $900 \mathrm{hPa}$ and divergence with weak winds between 900 and 700 $\mathrm{hPa}$ (Fig. 18c). The analysis results support the observation results of an abrupt increase in GNSS-PWV at Nakamichi from 14:30 LST to 15:30 LST (Fig. 16) and the appearance of the cloud and the echo system in the eastern region (Figs. 8, 9).

Finally, at the level of $700 \mathrm{hPa}$, the increase in $Q v$ after 12:00 LST appeared with strong WNW-ly wind (Fig. 18c), which covered on the Kofu Basin (not shown). We suggest that the GNSS-PWVs at Nirasaki, Makioka and Nakamichi increased gradually after 11:40, 11:50, and 12:00 LST, respectively (Fig. 16).

\section{Discussion}

\subsection{Moisture transport into the Kofu Basin from outside}

The analysis of 23 selected cases suggested that the SW-ly or SSW-ly wind passing through the valley between the Kofu Basin and the coastal region of Suruga Bay and the SE-ly wind in the east region entered the Kofu Basin from outside the basin. They brought air that was slightly cooler than that in the Kofu Basin (Fig. 6). Based on the case study, we identified a relatively warm and moist south-component wind below a height of $850 \mathrm{hPa}$ that blew through the cloud-free valleys connected to the coastal region of Suruga Bay, and a relatively warm and moist east-component wind below a height of $800 \mathrm{hPa}$ that blew in from the cloud- 

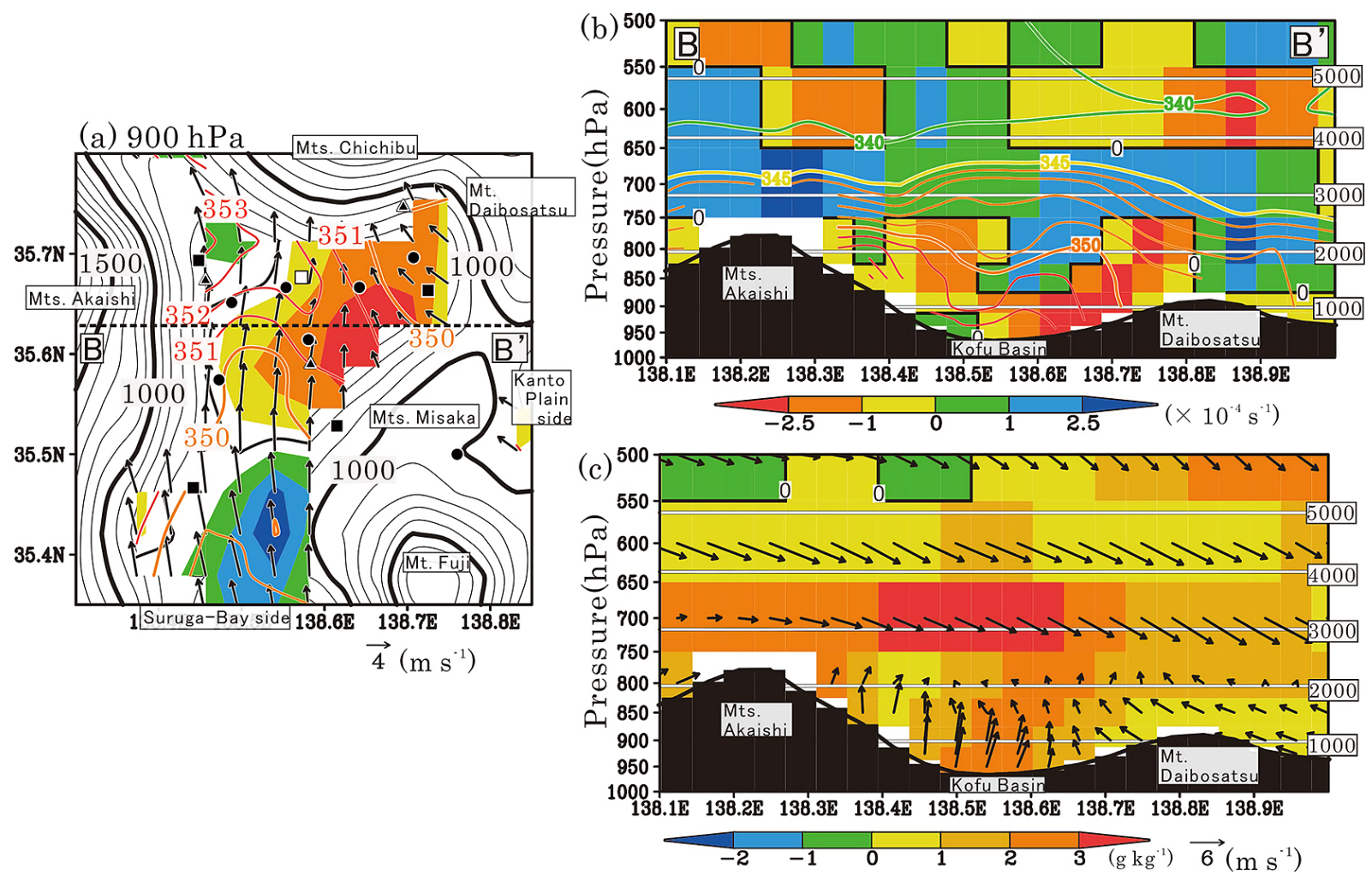

Fig. 18. (a) Horizontal section of equivalent potential temperature, horizontal wind and horizontal divergence in the Kofu Basin at $900 \mathrm{hPa}$, (b) vertical section of equivalent potential temperature $(\theta \mathrm{e})$, horizontal divergence and geo-potential height along line B-B' in (a), and (c) vertical profile of horizontal wind, $Q v$ difference from 15:00 to 12:00 LST and geo-potential height along line B-B' in (a), as derived by JMA-MANAL at 15:00 LST. The colored contours and color shaded areas in (a) and (b) indicate $\theta e$ and horizontal divergence (positive value: cold color) with the magnitude of $0 \mathrm{~s}^{-1}$ (black contours), respectively. The white contours in (b) and (c) indicate geo-potential height (unit: $\mathrm{m}$ ). The arrows in (a) and (c) indicate horizontal winds. The color shaded areas in (c) indicate the $Q v$ difference from 15:00 to 12:00 LST.

free valleys connected to the Kanto Plain (Figs. 8, 14, $15,17)$. Both winds passed over low mountain passes and entered the Kofu Basin with heat and aridity wherein a convective boundary layer reached a height of $800 \mathrm{hPa}$. Thus, $Q_{V}$ in the basin increased and the temperature decreased slightly.

Kimura and Kuwagata (1993) reported that the surface pressure at the bottom of a basin is lower than that outside the basin, which is associated with the temperature in the boundary layer within the basin becoming higher than that outside the basin. Plain-tobasin winds develop over mountain ridges and transport cooler air from the outside to inside the basin by passing over the ridge. Kuwagata and Kimura (1995) found that the up-valley wind in the Ina valley between the Akaishi Mountains and the Kiso Mountains in central Japan intensified with the thermal contrast increasing between the coastal and inland regions in central Japan in the late afternoon. It contributed to an increase in specific humidity in the valley with cold air advection. We consider that the thermal contrast below the height of $800 \mathrm{hPa}$ was formed between the Kofu Basin and the outside by the heating and the development of convective boundary layer in the Kofu Basin. Then, the south-component wind blowing in the valley connected to the coastal region of Suruga Bay and the east-component wind blowing in the valley connected to the Kanto Plain intensified and entered the Kofu Basin as SW-ly wind and SE-ly wind, respectively, causing the increase in $Q_{V}$ and the slight decrease in temperature at the surface. Thus, we consider that the atmosphere in the Kofu Basin changed 
from hot and dry to warm and moist because of the advection of warm and moist air from the outside, which contributed to the intensification of conditional instability and the formation of a cloud on the Kofu Basin.

\subsection{Local moisture concentration and vertical humidification over the Kofu Basin}

The analysis of the selected cases indicated that the intensification of convective instability over the Kofu Basin is associated with an increase in $\theta e$ at the lower layer and the appearance of primary precipitating cells over the region between the SW-ly or SSW-ly wind and the SE-ly wind at the surface (Figs. 4, 5, 6). In the case study, GNSS-PWV at Nakamichi increased abruptly only from 14:20 to 15:20 LST during the increases in $\theta \mathrm{e}$ and $Q_{V}$ on the Kofu Basin with the SW-ly wind in the central region and the SE-ly wind in the eastern region (Figs. 15, 16). After that, clouds appeared in the eastern region between the SW-ly wind and the SE-ly wind and the convective precipitating system was observed (Figs. 8d, 9). The analysis of JMA-MANAL data based on these observation results indicated that the horizontal convergence with a large $\theta \mathrm{e}$ was formed in the central and eastern regions of the Kofu Basin by the south-component wind from the valley connected to the coastal region of Suruga Bay and the SE-ly wind from the valley connected to the Kanto Plain. Thus, the $\theta$ e distribution shows a convex upward trend with horizontal convergence at the lower part and divergence at the upper part (Fig. 18).

Fujibe et al. (2002) reported that horizontal convergence within 10 to $20 \mathrm{~km}$ in the horizontal scale appeared before the occurrence of rainfall. Then, they suggested that the updraft and the moisture concentration associated with this horizontal convergence contributed to the formation of a convective precipitating system. We consider that the moisture transported to the Kofu Basin was concentrated in the region of horizontal convergence formed by the winds from both valleys. This, in turn, was connected to the vertical humidification by the lifting of the moisture in the local region, and it therefore contributed to cloud formation.

In addition, the increase in water vapor from 12:00 LST at the level of $700 \mathrm{hPa}$ with a strong WNW-ly wind was derived from the JMA-MANAL data (Fig. $18 \mathrm{c}$ ) and supported by the moderate increase in GNSS-PWVs at Nirasaki, Makioka and Nakamichi after 11:40 LST (Fig. 16). Iwasaki and Miki (2001) found that abundant moisture, which accumulated over the mountains, was transported toward the plain owing to the ambient wind or the counter flow. We also consider that the moisture on the western and northwestern mountains of the Kofu Basin was transported toward the basin, which contributed to the further intensification of the conditional instability on the basin.

Furthermore, from the analyses of the selected cases, the primary precipitating cells tends to appear on the central and eastern region of the Kofu Basin when the wind observed at Kofu before their appearance was SW-ly or SSW-ly (Fig. 6a). Then, the distribution of appearance of primary cells shifted to the west when the wind observed at Kofu was SE-ly (Fig. 6b). From the case study, the SW-ly wind was observed at Kofu before the appearance of precipitating cells in the central and eastern regions of the Kofu Basin (Figs. 14c, 15b). On the basis of the above results, it is suggested that the timing of the arrival of the SW-ly wind and the SE-ly wind in the central region of the Kofu Basin changes the region of horizontal convergence, which determines the appearance region of precipitating cells.

\subsection{Formation of precipitating cells}

In all cases, the appearance heights of the primary precipitating cells on the Kofu Basin were 2.25 to $6.25 \mathrm{~km}$ ASL (Fig. 2). In the case study, the six precipitating cells that composed the convective precipitating system appeared 3.25 to $6.25 \mathrm{~km} \mathrm{ASL}$ (Figs. 9, 10). The appearance positions were almost all in the eastern region of the Kofu Basin, wherein the clouds appeared after the formation of the horizontal convergence (Figs. 8d, 15c, 18a). Their heights were over the upper part of the convex-like distribution of $\theta \mathrm{e}$ with the increase in $Q_{V}$ in the vertical section at 15:00 LST, as derived by JMA-MANAL (Figs. 18b, c). Although a cumulus updraft and a trigger of a precipitating cell were not obtained directly by the observations and the JMA-MANAL data, we suggest that the precipitating cells were generated at a large altitude by the intensified cumulus updraft from the analysis of the vertical distributions of $Z_{D R}$ and $D V$ (Fig. 11).

Kobayashi et al. (2009) suggested that the difference in the average height of the first echoes between the mountain region (about $1.5 \mathrm{~km}$ ) and the plain region with the metropolitan area (above $3.0 \mathrm{~km}$ ) indicates a difference in the mechanism of convection between them. One possible trigger of a cumulonimbus cloud over the plain region with the metropolitan area is meso-scale surface convergence, which is almost similar to this case. In this case, clouds covered the 
mountain regions surrounding the Kofu Basin by noon (Fig. 8) but no precipitating cell appeared there. Fujibe et al. (2002) suggested that the updraft associated with developing convective clouds enhances the horizontal convergence within 10 to $20 \mathrm{~km}$, horizontally, at the surface. We consider that cumulus updrafts developed on the local region of the Kofu Basin in conjunction with the horizontal convergence at the surface. Some of the moisture lifted on the local region with the horizontal convergence was additionally lifted by cumulus updrafts, which contributed to the genesis of the precipitating cell at considerable height.

\section{Summary}

From 23 localized rainfall events on the Kofu Basin on a day of weak synoptic disturbance at the surface selected from 1 June to 30 September in 2012 to 2014, we investigated the characteristics of atmospheric conditions on the Kofu Basin preceding the appearance of the primary precipitating cell under weak synoptic disturbance at the surface. As a typical case, we conducted detailed analysis of this process on 25 July 2014.

The above results and discussions explain that the formation of localized rainfall in the Kofu Basin with heat and aridity in summer has its roots in the moisture transport associated with local surface winds to the Kofu Basin from the outside driven by the thermal contrast between the Kofu Basin and the outside. The transported moisture is then concentrated in the region wherein horizontal convergence is formed by the local surface winds, which decides on the region where a cloud appears with these lifting of the moisture. In addition, the moisture transport to the Kofu Basin at almost the same altitude as the mountain tops contributes to the intensification of conditional instability on the Kofu Basin. Thus, it is suggested that each cumulus updraft that appears over the region of horizontal convergence with the lifting of the moisture triggers the occurrence of a precipitating cell at a high altitude associated with the further lifting of moisture.

This explains one of the formation processes of a localized rainfall in a basin with heat and aridity associated with moisture transport to the basin in the water local circulation process derived thermally induced local circulation between a basin and the outside under weak synoptic disturbance in summer. Therewith, meteorological observations on a local scale to enable the high-accuracy understanding of local water circulation process is contributory to the monitoring of localized rainfall on a basin.

\section{Acknowledgments}

This study was funded by Grants-in-Aid for Scientific Research (No. 26750134) from Japan Society for the Promotion of Science. It was also supported by Social System Reformation Program for Adaptation to Climate Change under Japan Science and Technology Agency and Ministry of Education, Culture, Sports, Science and Technology (JST/MEXT) and the Global COE Program of University of Yamanashi (UY) directed by MEXT. We thank Professor Emeritus Kengo Sunada of UY and Professor Tadashi Suetsugi of Interdisciplinary Centre for River Basin Environment of UY (ICRE-UY) for their support of this study. The $\mathrm{X}$-MP radar of UY is operated by ICRE-UY. Some of the surface meteorological observation data were provided by NTT DOCOMO, Inc. GNSS data was provided by Hitachi Zosen Corporation. We thank Dr. Hiroshi Kobayashi of UY and Ms. Yuki Yoneyama of ICRE-UY for the surface meteorological observation. We also thank Dr. Tokio Kikuchi of Kochi University for providing MTSAT-2 data. The data of Meso-Scale Model of the JMA were collected and distributed by Research Institute for Sustainable Humanosphere, Kyoto University (http://database.rish.kyoto-u.ac.jp/ index-e.html). The Grid Analysis and Display System (GrADS) was used to draw the figures. We express our appreciation to Dr. Ryohei Misumi and anonymous reviewers for their helpful comments.

\section{References}

Bavis, M., S. Businger, T. A. Herring, C. Rocken, R. A. Anthes, and R. H. Ware, 1992: GPS meteorology: Remote sensing of atmospheric water vapor using the global positioning system. J. Geophys. Res., 97, $15787-15801$.

Brandes, E. A., J. Vivekanandan, J. D. Tuttle, and C. J. Kessinger, 1995: A study of thunderstorm microphysics with multiparameter radar and aircraft observation. Mon. Wea. Rev., 123, 3129-3143.

Chen, C.-S., C.-L. Liu, M.-C. Yen, C.-Y. Chen, P.-L. Lin, C.-Y. Huang, and J.-H. Teng, 2010: Terrain effects on an afternoon heavy rainfall event, observed over northern Taiwan on 20 June 2000 during monsoon break. J. Meteor. Soc. Japan, 88, 649-671.

Cressman, G. P., 1959: An operational objective analysis system. Mon. Wea. Rev., 87, 367-374.

Fujibe, F., 1988: Diurnal variations of precipitation and thunderstorm frequency in Japan in the warm season. Pap. Meteor. Geophys., 39, 79-94.

Fujibe, F., K. Sakagami, K. Chubachi, and K. Yamashita, 2002: Surface wind patterns in Tokyo in the preceding afternoon short-time heavy rainfall of midsummer days. Tenki, 49, 395-405 (in Japanese with English abstract). 
Gal-Chen, T., 1982: Errors in fixed and moving frame of references: Applications for conventional and Doppler radar analysis. J. Atmos. Sci., 39, 2279-2300.

Honda, Y., M. Nishijima, K. Koizumi, Y. Ohta, K. Tamiya, T. Kawabata, and T. Tsuyuki, 2005: A pre-operational variational data assimilation system for a nonhydrostatic model at the Japan Meteorological Agency: Formulation and preliminary results. Quart. J. Roy. Meteor. Soc., 131, 3465-3475.

Iwasaki, H., 2004: Diurnal variation of precipitable water and convective activity with dual maxima in summer season around Mt. Tanigawa in the northern Kanto district, Japan. J. Meteor. Soc. Japan, 82, 805-816.

Iwasaki, H., and T. Miki, 2001: Observational study on the diurnal variation in precipitable water associated with the thermally induced local circulation over the "Semi-Basin" around Maebashi using GPS data. J. Meteor. Soc. Japan, 79, 1077-1091.

Kanda, M., and M. Tsunoi, 1995: Wind and temperature fields in the Kofu basin in summer. Tenki, 42, 763-771 (in Japanese).

Kimura, F., and T. Kuwagata, 1993: Thermally induced wind passing from plain to basin over a mountain range. J. Appl. Meteor., 32, 1538-1547.

Kimura, F., and T. Kuwagata, 1995: Horizontal heat fluxes over complex terrain computed using a simple mixedlayer model and a numerical model. J. Appl. Meteor., 34, 549-558.

Kobayashi, F., M. Imai, H. Sugawara, M. Kanda, and H. Yokoyama, 2009: Generation of cumulonimbus first echoes in the Tokyo metropolitan region on mid-summer days. Proceedings of The 7th International Conference on Urban Climate, Yokohama, Japan, 4 pp.

Kumjian, M. R., A. P. Khain, N. Benmoshe, E. Ilotoviz, A. V. Ryzhkov, and V. T. J. Ryzhkov, 2014: The anatomy and physics of $Z_{D R}$ columns: Investigating a polarimetric radar signature with a spectral bin microphysical model. J. Appl. Meteor. Climatol., 53, 1820-1843.

Kuwagata, T., and F. Kimura, 1995: Daytime boundary layer evolution in a deep valley. Part I: Observations in the Ina Valley. J. Appl. Meteor., 34, 1082-1091.

Park, S.-G., M. Maki, K. Iwanami, V. N. Bringi, and V.
Chandrasekar, 2005: Correction of radar reflectivity and differential reflectivity for rain attenuation at $\mathrm{X}$ band. Part II: Evaluation and application. J. Atmos. Oceanic Technol., 22, 1633-1655.

Saito, K., T. Fujita, Y. Yamada, J. Ishida, Y. Kumagai, K. Aranami, S. Ohmori, R. Nagasawa, S. Kumagai, C. Muroi, T. Kato, H. Eito, and Y. Yamazaki, 2006: The operational JMA nonhydrostatic mesoscale model. Mon. Wea. Rev., 134, 1266-1298.

Saito, T., and F. Kimura, 1998: Diurnal Variation of Convective Precipitation in Chubu-Kanto Area in the Summer. Tenki, 45, 541-549 (in Japanese).

Sano, T., and K. Tsuboki, 2006: Structure and evolution of a cumulonimbus cloud developed over a mountain slope with the arrival of sea breeze in summer. $J$. Meteor. Soc. Japan, 84, 613-640.

Sano, T., S. Oishi, T. Nakamura, and K. Sunada, 2012a: Analyses of distribution and increasing mechanism of rain over mountain slopes surrounding a basin using X-MP radar. J. Japan Soc. Civ. Eng., Ser. B1 (Hydraulic Engineering), 68, I_355-I_360 (in Japanese with an English abstract).

Sano, T., S. Oishi, and K. Sunada, 2012b: Structure, maintenance and development of a stationary convective system generated over a mountain slope adjoining a bay in summer. J. Meteor. Soc. Japan, 90, 807-831.

Sano, T., T. Suetsugi, and S. Oishi, 2014: Characteristics of distribution and preceding surface conditions of cumulonimbus clouds appeared on Kofu Basin on a calm day in summer. J. Japan Soc. Civ. Eng., Ser. B1 (Hydraulic Engineering), 70, I_889-I_894 (in Japanese with an English abstract).

Sato, T., and F. Kimura, 2005: Diurnal cycle of convective instability around the central mountains in Japan during the warm season. J. Atmos. Sci., 62, 16261636.

Shusse, Y., K. Tsuboki, B. Geng, H. Minda, and T. Takeda, 2005: Structure and evolution of deeply developed convective cells in a long-lived cumulonimbus cloud under a weak vertical wind-shear condition. J. Meteor. Soc. Japan, 83, 351-371. 